\title{
Imaging Dopamine and Serotonin Systems on MPTP Monkeys: A Longitudinal PET Investigation of Compensatory Mechanisms
}

\author{
Benedicte Ballanger, ${ }^{1,2}$ Maude Beaudoin-Gobert, ${ }^{1,2}$ Sara Neumane, ${ }^{1,2}$ Justine Epinat, ${ }^{1,2}{ }^{-}$Elise Metereau, ${ }^{1,2}$ \\ Sandra Duperrier, ${ }^{1,2}$ Emmanuel Broussolle, ${ }^{1,2,5}$ Stephane Thobois, ${ }^{1,2,5}$ Frederic Bonnefoi, ${ }^{3}$ Christian Tourvielle, ${ }^{3}$ \\ Franck Lavenne, ${ }^{3}$ Nicolas Costes, ${ }^{3}$ Didier Lebars, ${ }^{2,3,4,5}$ Luc Zimmer, ${ }^{2,3,5}$ (E) Véronique Sgambato-Faure, ${ }^{1,2}$ \\ and $\odot$ Léon Tremblay ${ }^{1,2}$ \\ ${ }^{1}$ Centre de Neurosciences Cognitives, Unité Mixte de Recherche 5229 Centre National de la Recherche Scientifique, Bron 69675, France, ${ }^{2}$ Université Claude \\ Bernard Lyon 1, Villeurbanne 69100, France, ${ }^{3}$ Centre d'Exploration et de Recherche Médicale par Emission de Positons, Imagerie du vivant, Bron 69677, \\ France, ${ }^{4}$ Institut de Chimie et de Biochimie Moléculaires et Supramoléculaires, Unité Mixte de Recherche 5246 Centre National de la Recherche \\ Scientifique, Lyon 69622, France, and ${ }^{5}$ Hospices Civils de Lyon, Lyon 69229, France
}

It is now widely accepted that compensatory mechanisms are involved during the early phase of Parkinson's disease (PD) to delay the expression of motor symptoms. However, the neurochemical mechanisms underlying this presymptomatic period are still unclear. Here, we measured in vivo longitudinal changes of both the dopaminergic and serotonergic systems in seven asymptomatic 1-methyl-4phenyl-1,2,3,6-tetrahydropyridine (MPTP)-intoxicated monkeys (when motor symptoms are less apparent) using PET. We used the progressively MPTP-intoxicated monkey model that expresses recovery from motor symptoms to study the changes in dopamine synthesis $\left(\left[{ }^{18} \mathrm{~F}\right] \mathrm{DOPA}\right)$, dopamine $\mathrm{D}_{2} / \mathrm{D}_{3}$ receptors $\left(\left[{ }^{11} \mathrm{C}\right]\right.$ raclopride), and serotonin transporter ${ }^{11} \mathrm{C}-\mathrm{N}, \mathrm{N}$-dimethyl-2-(-2-amino-4cyanophenylthio) benzylamine $\left(\left[{ }^{11} \mathrm{C}\right] \mathrm{DASB}\right)$ and serotonin $1 \mathrm{~A}$ receptor $\left(\left[{ }^{18} \mathrm{~F}\right] \mathrm{MPPF}\right)$ levels between four different states (baseline, early symptomatic, full symptomatic and recovered). During the early symptomatic state, we observed increases of $\left[{ }^{18} \mathrm{~F}\right] \mathrm{DOPA}$ uptake in the anterior putamen, $\left[{ }^{11} \mathrm{C}\right]$ raclopride binding in the posterior striatum, and $2^{\prime}$-methoxyphenyl-(N-2'-pyridinyl)-p- $\left[{ }^{18} \mathrm{~F}\right]$ fluorobenzamidoethylpiperazine $\left[{ }^{18} \mathrm{~F}\right] \mathrm{MPPF}$ uptake in the orbitofrontal cortex and dorsal ACC. After recovery from motor symptoms, the results mainly showed decreased $\left[{ }^{11} \mathrm{C}\right]$ raclopride binding in the anterior striatum and limbic ACC. In addition, our findings supported the importance of pallidal dopaminergic neurotransmission in both the early compensatory mechanisms and the functional recovery mechanisms, with reduced aromatic L-amino acid decarboxylase (AAAD) activity closely related to the appearance or perseveration of motor symptoms. In parallel, this study provides preliminary evidence of the role of the serotonergic system in compensatory mechanisms. Nonetheless, future studies are needed to determine whether there are changes in SERT availability in the early symptomatic state and if $\left[{ }^{18} \mathrm{~F}\right]$ MPPF PET imaging might be a promising biomarker of early degenerative changes in PD.

Key words: compensatory mechanisms; dopamine; MPTP; Parkinson's disease; PET imaging; serotonin

Significance Statement

The present research provides evidence of the potential of combining a multitracer PET imaging technique and a longitudinal protocol applied on a progressively 1-methyl-4-phenyl-1,2,3,6-tetrahydropyridine-intoxicated monkey model to further elucidate the nature of the compensatory mechanisms involved in the preclinical period of Parkinson's disease (PD). In particular, by investigating the dopaminergic and serotonergic changes both presynaptically and postsynaptically at four different motor states (baseline, early symptomatic, full symptomatic, and recovered), this study has allowed us to identify putative biomarkers for future therapeutic interventions to prevent and/or delay disease expression. For example, our findings suggest that the external pallidum could be a new target for cell-based therapies to reduce PD symptoms. 


\section{Introduction}

Parkinson's disease (PD) is a neurodegenerative disorder clinically characterized by the progressive emergence of motor symptoms. However, those impairments are observed only when the striatal level of DA has decreased by 60-80\% (Bernheimer et al., 1973). During the early phase of the disease, parkinsonian patients do not show motor symptoms despite progressive but strong dopaminergic depletion. This suggests the existence of impressive compensatory mechanisms in this presymptomatic period to counterbalance the degenerative process (Zigmond, 1997). Human PET imaging studies have shown that, early in the disease, the activity of the enzyme aromatic L-amino acid decarboxylase (AAAD) is increased in the preserved striatal dopaminergic terminals (Lee et al., 2000; Ribeiro et al., 2002), as well as in extrastriatal structures such as the pallidum (Whone et al., 2003) and the cingulate cortex (Rakshi et al., 1999). In addition, increased dopamine (DA) release (Snyder et al., 1990; Schneider et al., 1994) or turnover by the remaining axons (Agid et al., 1973; Altar et al., 1987) and increased numbers or sensitivity of the DA receptors (Zigmond et al., 1984; Bezard and Gross, 1998) have been observed in PD animal models. Altogether, these findings have emphasized the role of dopaminergic compensatory mechanisms. Nonetheless, nondopaminergic systems could also play a role in compensation, such as the GABAergic (Schroeder and Schneider, 2002), glutamatergic (Bezard et al., 1998), and serotonergic systems (Gaspar et al., 1993; Mounayar et al., 2007; Boulet et al., 2008). The precise neurochemical mechanisms involved during the early phase of the disease are still unclear.

To gain further understanding of these compensatory mechanisms, we previously used a progressive approach of 1-methyl-4-phenyl-1,2,3,6-tetrahydropyridine (MPTP)-intoxicated monkey model of PD (Mounayar et al., 2007; Boulet et al., 2008; Neumane et al., 2012). With this method, monkeys developed all the motor symptoms and then fully recovered after the final MPTP injection despite a large DA denervation, suggesting that compensatory mechanisms could be involved in the recovery process. Overall, our studies supported the notion that residual striatal DA played a role in compensation in $\mathrm{PD}$, revealed the importance of extrastriatal structures such as the external pallidum, and highlighted the possible involvement of serotonin (5-HT). However, the conclusions were limited because the observed changes were restricted to the subcortical presynaptic level and there is no evidence yet that the recovery process involves the same mechanisms as those involved during the presymptomatic state of PD when the level of dopaminergic lesion is less pronounced.

Accordingly, in the present study, we combined a multitracer PET imaging method and a longitudinal protocol using this progressively MPTP-intoxicated monkey model of PD to investigate the in vivo changes in the DA and 5-HT systems both at the presynaptic and the postsynaptic levels. Because functional com-

Received May 20, 2015; revised Dec. 3, 2015; accepted Dec. 22, 2015.

Author contributions: B.B., E.B., S.T., F.L., N.C., D.L., L.Z., V.S.-F., and L.T. designed research; B.B., M.B.-G., S.N., J.E., E.M., F.B., C.T., F.L., N.C., D.L., L.Z., V.S.-F., and L.T. performed research; B.B., E.M., S.D., N.C., and L.T. analyzed data; B.B. and L.T. wrote the paper.

This work was supported by the French National Agency of Research (Grant ANR-09-MNPS-018). We thank Jean-Luc Charrieau and Fabrice Hérant for expert animal care and C. Kennard for proofreading of the manuscript and English corrections.

The authors declare no competing financial interests.

Correspondence should be addressed to Léon Tremblay, CNRS UMR5229, 67 Boulevard Pinel, 69675 Bron cedex, France. E-mail: leon.tremblay@isc.cnrs.fr.

DOI:10.1523/JNEUROSCI.2010-15.2016

Copyright $\odot 2016$ the authors $\quad 0270-6474 / 16 / 361578-13 \$ 15.00 / 0$ pensatory mechanisms might differ depending on the extent of dopaminergic denervation, we successively observed the changes between four different motor states, starting from baseline, followed by an early symptomatic and then a full symptomatic parkinsonian state, and proceeding to the recovered state. We used both the $\left[{ }^{18} \mathrm{~F}\right] \mathrm{DOPA}$ (thought to reflect AAAD activity) and $\left[{ }^{11} \mathrm{C}\right]$ raclopride (a selective dopamine $\mathrm{D}_{2} / \mathrm{D}_{3}$ receptors antagonist) radiotracers to identify regions with dopaminergic dysfunctions, as described previously in human studies (for review, see Brooks and Pavese, 2011). Abnormalities in both serotonin transporter (SERT) availability (Politis et al., 2010a, 2010b) and $5-\mathrm{HT}_{1 \mathrm{~A}}$ receptors (Ballanger et al., 2012) have been associated with depression in PD patients, a nonmotor symptom that often appears years before motor disturbances. Therefore, follow-up of the serotonergic system has been addressed using the ${ }^{11} \mathrm{C}-\mathrm{N}, \mathrm{N}$-dimethyl-2-(-2-amino-4-cyanophenylthio) benzylamine ([ $\left.\left.{ }^{11} \mathrm{C}\right] \mathrm{DASB}\right)$ (a specific marker of SERT availability) and $2^{\prime}$-methoxyphenyl-(N-2'-pyridinyl)-p- $\left[{ }^{18} \mathrm{~F}\right]$ fluoro-benzamidoethylpiperazine $\left(\left[{ }^{18} \mathrm{~F}\right] \mathrm{MPPF}\right)$ (a selective $5-\mathrm{HT}_{1 \mathrm{~A}}$ receptor antagonist) radiotracers to identify regions with respectively presynaptic and/or postsynaptic 5-HT dysfunctions. We hypothesized that there would be an early increase in presynaptic DA activities in structures less affected by MPTP toxicity, followed by a profound decrease during the full parkinsonian motor state, whereas the recovery process should involve modifications in DA receptors and 5-HT compensatory activities.

\section{Materials and Methods}

Animals. Seven male cynomolgus monkeys (Macaca fascicularis, MF) between 3 and 5 years old (young adults) and weighing 4-6 kg were provided by Tamarinier Ltee, Mauritius Island and used in this study. These monkeys were cared for and treated in strict accordance with National Institutes of Health guidelines (1996) and with the European Community Council Directive of 2010 (2010/63/UE) and the recommendations of the French National Committee (2013/11).

MPTP treatment and experimental schedule. The timeline of the experimental design is shown in Figure 1A. After collection of baseline PET imaging data, the animals were given intramuscular MPTP injections $(0.3-0.6 \mathrm{mg} / \mathrm{kg}$ body weight; Sigma-Aldrich) performed under light anesthesia (ketamine $0.5 \mathrm{mg} / \mathrm{kg}$, atropine $0.05 \mathrm{mg} / \mathrm{kg}$ ) at intervals of $4-5 \mathrm{~d}$ until the emergence of most of the motor parkinsonian symptoms. The total MPTP dose given to each monkey varied between 1.2 and $2.2 \mathrm{mg} / \mathrm{kg}$. Once MPTP injections were stopped, almost all the animals (5/7) totally recovered spontaneously from their motor symptoms (Fig. 1C).

Throughout the study, the severity of parkinsonism was evaluated using the rating scale proposed by Schneider and Kovelowski (1990). We have already described the effects of MPTP evaluated using this rating scale in previous studies (Pessiglione et al., 2004; Mounayar et al., 2007; Boulet et al., 2008). Briefly, this scale includes 12 items rated between 0 and 2 or 3, with a total score of 29. It takes into account classical motor symptoms (bradykinesia, rigidity, tremor, freezing, posture and arm posture), but also spontaneous activities (arm movements, spontaneous eye movements, and home cage activity) and other activities (vocalization, triggered eye movements, and feeding). For each monkey, the evolution of these measurements was evaluated daily by one or two experimenters accustomed to handling the animals. Moreover, all of the evaluation sessions were recorded to allow additional evaluations by an experimenter blinded to the state of the animal. During these additional evaluations, the intensity of some items was evaluated by quantitative measurement of specific events (counting of eye and arm movements and home cage activity), which were statistically compared with measurements made during baseline periods before MPTP treatment. For these measurements, a score of 1,2 , or 3 indicated a statistical reduction of $>50 \%$, a statistical reduction of $>90 \%$, or a complete absence of movement, respectively. Some symptoms were evaluated specifically in either the chair (rigidity, spontaneous and triggered eye movements, and 
A

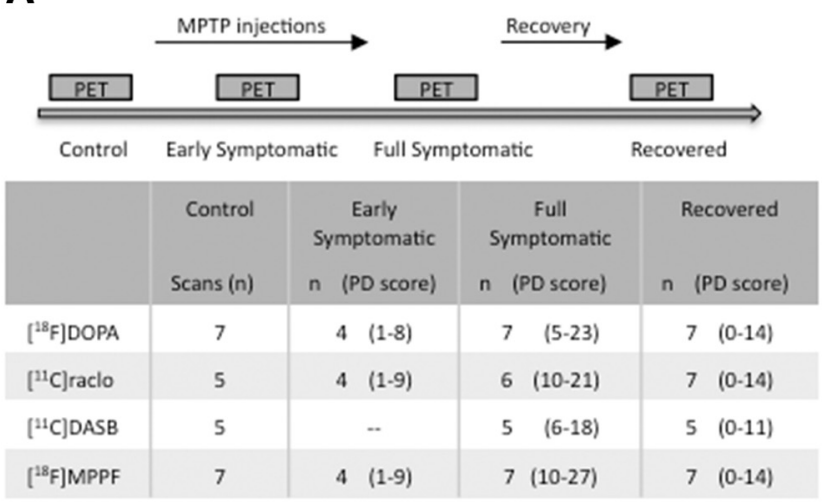

\section{C}

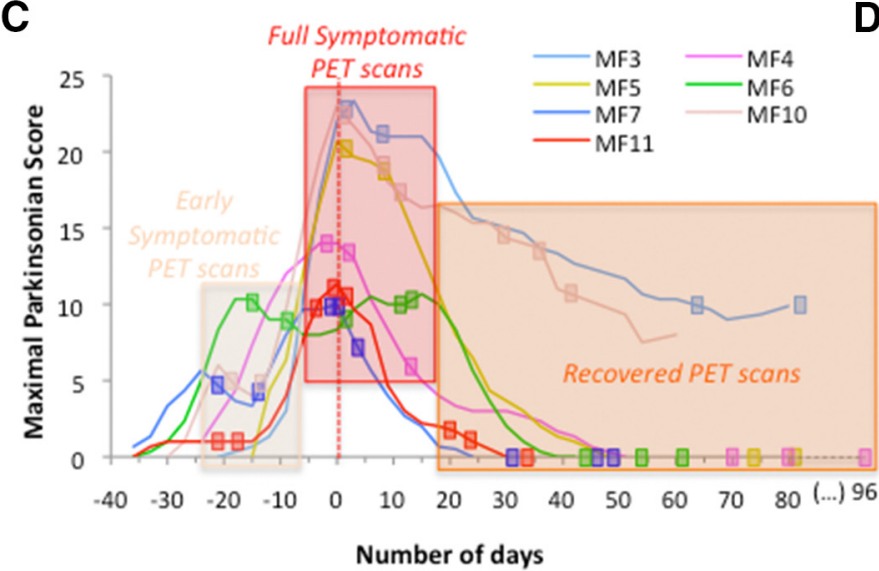

B

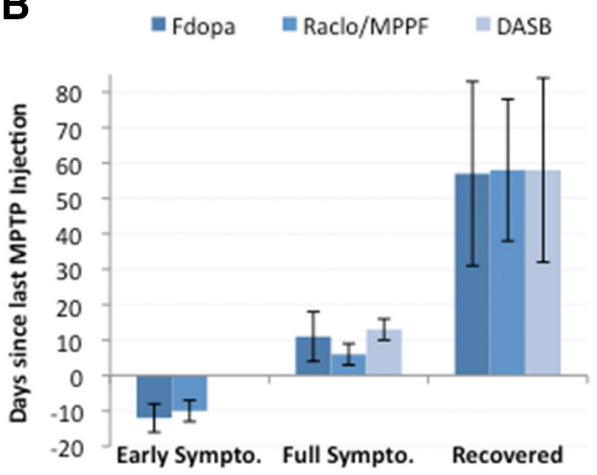

D

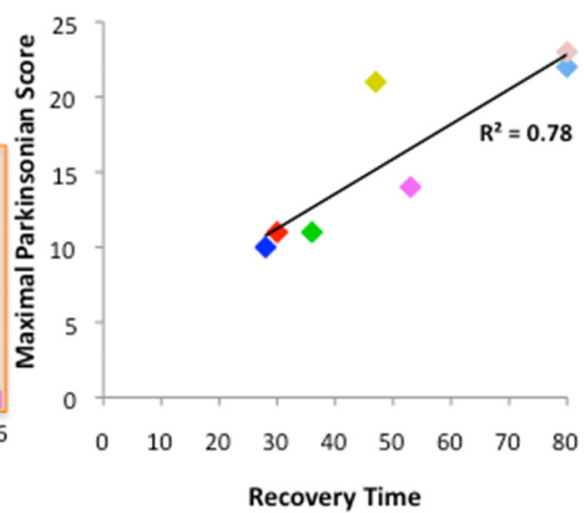

Figure 1. Study design and schedule of PET scan acquisitions. $A$, Timeline of the experimental design with the number ( $n$ ) of animals in each state and for each radioligand. $\boldsymbol{B}$, Mean time (days) \pm SD between last MPTP injection and PET acquisition for each radioligand. C, Evolution of parkinsonian score during MPTP intoxication and recovery. Data represent the evolution of appearance and disappearance of motor symptoms during and after MPTP intoxication. Timelines are aligned such that day 0 corresponds to the day on which the maximal parkinsonian score was obtained from an individual animal. The rectangle represents PET scan acquisition. $D$, Positive correlation between maximal parkinsonian score and the time needed for each animal to recover spontaneously from their motor symptoms once MPTP injections were stopped $(n=7)$.

arm movements during tasks) or the cage (home cage activity), whereas the other symptoms were evaluated in both the chair and the cage (bradykinesia/akinesia, posture). The home cage activity was evaluated using closed circuit television and an activity digitalization system (Vigie Primates; for details, see Mounayar et al., 2007).

PET scans were acquired longitudinally at four different times: (1) in the baseline state, (2) in the early symptomatic state (4-5 d after the second MPTP injection), (3) in the full symptomatic state (between 4 and $14 \mathrm{~d}$ after the last MPTP injection during the peak of motor symptoms), and (4) in the recovered state (at least 1 week after the parkinsonian score returned to 0 ). However, it was not possible to undertake PET with all of the radiotracers in all of the animals, which therefore explains the different number of animals within each state (Fig. 1A). The mean time (days) between last MPTP dose and PET scans was (mean \pm SD) $-11 \pm 3$ for the early symptomatic state, $9 \pm 5$ for the full symptomatic state, and $59 \pm 22$ for the recovered state (Fig. $1 B$ ). On the day of each PET scan, the monkeys were pretreated with atropine $(0.05 \mathrm{mg} / \mathrm{kg})$ and $15 \mathrm{~min}$ later were anesthetized by an intramuscular dose of zoletil (15 mg/kg). The monkeys were then transported to the Imaging Centre (CERMEP, Lyon, France), where they were placed in a PET-compatible stereotaxic apparatus. Anesthesia was maintained during the scan and a lactated Ringer's solution was infused continuously through a saphenous vein catheter. The respiratory frequency, $\mathrm{pO}_{2}$, and heart rate were monitored throughout the experiment.

PET data acquisition. All PET scans were performed in 3D mode using a Siemens CTI HR + tomograph, with an axial field of view of $15.2 \mathrm{~cm}$, yielding 63 planes and a nominal in-plane resolution of $4.1 \mathrm{~mm}$ FWHM according to the NEMA protocol (Brix et al., 1997). PET measurements were performed with four radiotracers: $\left[{ }^{18} \mathrm{~F}\right] \mathrm{DOPA},\left[{ }^{11} \mathrm{C}\right]$ raclopride, $\left[{ }^{11} \mathrm{C}\right] \mathrm{DASB}$, and $\left[{ }^{18} \mathrm{~F}\right] \mathrm{MPPF}$. For each experimental state, the mean time (days) between PET scans was (mean \pm SD) $20 \pm 13$ for the baseline state, $5 \pm 2$ for the early symptomatic state, $7 \pm 4$ for the full symptomatic state, and $12 \pm 6$ for the recovered state. It should be noted that the $\left[{ }^{11} \mathrm{C}\right]$ raclopride and $\left[{ }^{18} \mathrm{~F}\right]$ MPPF PET scans were always acquired in $1 \mathrm{~d}$, with the $\left[{ }^{11} \mathrm{C}\right]$ raclopride collected first due to the short half-life of carbon-11. Except for those two ligands, the order of PET scans was randomized for each monkey and each state to avoid, as far as possible, the neurochemical effects of anesthesia. Although we cannot exclude that repeated anesthesia may have had an effect on our PET results, it is worth mentioning that treatment with zoletil does not affect the binding of dopaminergic and serotonergic transporters' radioligands (Elfving et al., 2003).

Before the tracer injection, a transmission scan (68 Ge rotating rod sources; $10 \mathrm{~min}$ ) was acquired to correct for tissular $511 \mathrm{keV}$ gamma attenuation. Dynamic acquisition started with the intravenous injection of the radiotracer and lasted $100 \mathrm{~min}$ for $\left[{ }^{18} \mathrm{~F}\right] \mathrm{DOPA}, 90 \mathrm{~min}$ for $\left[{ }^{11} \mathrm{C}\right] \mathrm{DASB}, 70$ min for $\left[{ }^{18} \mathrm{~F}\right] \mathrm{MPPF}$, and $60 \mathrm{~min}$ for $\left[{ }^{11} \mathrm{C}\right]$ raclopride PET scans. Synthesis of radioligands was performed in the cyclotron unit of the CERMEP. The mean doses $( \pm \mathrm{SD})$ of injected $\left[{ }^{18} \mathrm{~F}\right] \mathrm{DOPA},\left[{ }^{11} \mathrm{C}\right]$ raclopride, $\left[{ }^{11} \mathrm{C}\right] \mathrm{DASB}$, and $\left[{ }^{18} \mathrm{~F}\right] \mathrm{MPPF}$ were $139 \pm 24,143.9 \pm 29.6,156.9 \pm 20$, and $136.2 \pm 28.1 \mathrm{MBq}$, respectively. The $3 \mathrm{D}$ emission data were reconstructed with attenuation and scatter correction by a 3D filtered back projection (Hamming filter; cutoff frequency, 0.5 cycles/pixel) algorithm and a zoom factor of three. Reconstructed volumes were $128 \times 128$ matrices of $0.32 \times 0.32 \mathrm{~mm}^{2}$ pixels in 63 $2.42 \mathrm{~mm}$ spaced planes.

PET data preprocessing. To obtain parametric images, the PET studies were analyzed by suitable tracer kinetic modeling. The parameters computed were the uptake rate $\left(K_{\mathrm{i}}, 10^{-3} \mathrm{~min}^{-1}\right)$ for $\left[{ }^{18} \mathrm{~F}\right] \mathrm{DOPA}$ and the $\mathrm{BP}_{\mathrm{ND}}$ of $\left[{ }^{11} \mathrm{C}\right]$ raclopride, $\left[{ }^{11} \mathrm{C}\right] \mathrm{DASB}$, and $\left[{ }^{18} \mathrm{~F}\right] \mathrm{MPPF}$. The $\left[{ }^{18} \mathrm{~F}\right] \mathrm{DOPA}$ $K_{\mathrm{i}}$ was calculated using frames recording for between 30 and $90 \mathrm{~min}$ for 
Table 1. Dopaminergic cell loss

\begin{tabular}{lllll}
\hline & \multicolumn{2}{l}{ Dopaminergic cell loss (\%) } & \\
\cline { 2 - 4 } Monkey & A8 & A9 & A10 & Total \\
\hline MF3 & 74 & 86.4 & 73.2 & 78 \\
MF4 & 71.6 & 75.4 & 65.1 & 70.8 \\
MF5 & 72 & 80.8 & 68.1 & 73.8 \\
MF6 & 58.1 & 78.2 & 50.4 & 62.5 \\
MF7 & 71 & 68.3 & 61 & 66.9 \\
MF10 & Data not available & & & \\
MF11 & 81.4 & 67.8 & 58 & 69.5 \\
Mean & 71.4 & 76.2 & 62.6 & 70.3 \\
SD & 7.5 & 7.2 & 8 & 5.4 \\
\hline
\end{tabular}

Data represent the percentage of neuronal loss in the substantia nigra collected for each monkey (MF) at the end of the study (with the exception of MF10).

the linearization and the Patlak graphical analysis, considering the cerebellum as the reference area. Parametric images of $\mathrm{BP}_{\mathrm{ND}}$ were obtained using a simplified reference tissue model (Gunn et al., 1997) with the cerebellum as the reference. Using Statistical Parametric Mapping (SPM8, Wellcome Trust Centre for NeuroImaging, University College London) in MATLAB (version 8.1, R2013a; The MathWorks), the parametric images were transformed into a common space using the brain Macaca fascicularis MRI template (Ballanger et al., 2013) available from http://www.cermep.fr (section download/atlas). Finally, a Gaussiansmoothing kernel of $6 \mathrm{~mm}$ was applied to the normalized parametric images to localize significant changes at the voxel level.

ROI-based analysis. Tissue time-activity concentration curves were extracted using our maximum probability atlas (Ballanger et al., 2013) for eight ROIs within the BG (namely the anterior and posterior parts of the putamen, the caudate nucleus, the ventral striatum, and the external and internal segments of the pallidum), as well as 11 other ROIs within the thalamus; the raphe nucleus; the dorsal and ventral parts of the ACC; the dorsolateral, medial, orbital, and ventral parts of the frontal cortex; the amygdala; the hippocampus; and the insula considering regional distribution of DA and 5-HT.

Histological procedures for dopaminergic cell loss. At the end of the experiments, the monkeys received a lethal overdose of anesthetic drug (pentobarbital) and were then transcardially perfused with saline, followed by $5 \mathrm{~L}$ of $4 \%$ paraformaldehyde fixative solution. The brains were removed from the skull, immersed in PBS with 20\% sucrose for $48 \mathrm{~h}$, frozen, and cut into 50 - $\mu \mathrm{m}$-thick frontal sections perpendicular to the intercommissural plane, which were stored for immunohistochemical procedures (see details in Jan et al., 2000). Dopaminergic innervation of the SN cell loss was studied by immunocytochemical localization of TH (see details in Mounayar et al., 2007). In the SNc, TH-positive cells were counted in nine regularly spaced sections covering the anteroposterior extent of the structure using an image analysis system (Mercator; ExploraNova). The sections were matched anatomically in each of the animals and the total number of TH-positive cells was estimated after correction using the Abercrombie method. The percentage of neuronal loss in the SNc was evaluated by comparison with baseline values from four intact monkeys (Table 1).

Statistical analyses. Statistical differences in ROIs $K_{\mathrm{i}}$ and $\mathrm{BP}_{\mathrm{ND}}$ among the four different states were assessed using two-way repeated-measures ANOVA, followed by the Holm post hoc test (see Table 2 for details). It should be noted that the $\left[{ }^{11} \mathrm{C}\right] \mathrm{DASB}$ PET scan of MF11 collected in the recovered state was excluded for technical reasons. Nonlinear multivariate regressions were used to analyze dependences between the behavioral markers (motor scores and recovery time), the histological markers ( $\mathrm{SN}$ cell loss), and the different binding parameters. For all of the statistical analyses performed using STATA 10.0/SE (StataCorpLP), a probability level of $<5 \%(p<0.05)$ was considered to be significant.

In parallel, for an exploratory search involving the entire cortex, we also performed on the normalized parametric images voxel-by-voxel analyses using SPM8 software. Due to the small sample size, statistical maps were thresholded at a level of $p<0.001$ uncorrected with an extent threshold of at least 80 contiguous voxels. For visualization, voxelwise levels of significance ( $t$-maps) were projected onto the MF MRI template (Ballanger et al., 2013).

\section{Results \\ MPTP intoxication, evolution of motor score during intoxication, and recovery}

The monkeys received 3-5 injections of MPTP for a cumulative dose of 1.2 to $2.2 \mathrm{mg} / \mathrm{kg}$ (mean $1.6 \mathrm{mg} / \mathrm{kg}$ ). Four monkeys (MF6, MF7, MF10, and MF11) were scanned in an early symptomatic state after two MPTP injections (parkinsonian scores of 8, 6, 5, and 1 , respectively, at the time of the $\left[{ }^{18} \mathrm{~F}\right] \mathrm{DOPA}$ scan and of 9,3 , 5 , and 1 , respectively, at the time of the $\left[{ }^{11} \mathrm{C}\right]$ raclopride and $\left[{ }^{18} \mathrm{~F}\right] \mathrm{MPPF}$ scans; Fig. $\left.1 \mathrm{C}\right)$. Among those animals, MF6 already presented overt mild motor symptoms (including bradykinesia, rigidity, freezing, and parkinsonian posture) and a slight reduction in the analysis of home cage activity and spontaneous eye movements associated with a mild parkinsonian posture were reported in the other animals. After full MPTP intoxication, all animals (7/7) developed motor symptoms and exhibited recovery after stopping treatment (Fig. 1C). Recovery was complete for most of the monkeys (5/7), whereas two monkeys (MF3 and MF10) presented only a partial recovery with mild motor symptoms (parkinsonian scores of 9 and 8, respectively, at the end; Fig. 1C). Of particular interest, in both monkeys, bradykinesia, parkinsonian posture, and a reduction in home cage activity were still observed during the recovery period. Interestingly, the maximal parkinsonian score obtained for those 2 monkeys (22.5 \pm 0.7 ) was greater than the maximal score observed in monkeys with total recovery $(13.4 \pm 4.5)$. Recovery after the maximal effect and cessation of MPTP injections was gradual over 4-8 weeks (mean $38.8 \pm 10.9$ d to maximal recovery; Fig. $1 C$ ). No correlation was found between the motor score and the cumulative dose of MPTP received by each animal $(r=0.63, p=0.13$, $n=7$ ). A positive correlation was found between the motor score and the recovery time $(r=0.85, p=0.015, n=7)$, indicating that, the greater the maximal effect, the longer the time to recovery (Fig. $1 D$ ). Finally, the maximal motor score was positively correlated with the total dopaminergic cell death in the SN $(r=$ $0.87, p=0.023, n=6$ ). Specifically, cell death in A9 and A10 were significantly correlated with motor scores $(r=0.85, p=0.032$ and $r=0.84, p=0.036$, respectively, $n=6$ ). It is worth noting that cell death in A8 was not correlated with motor scores $(r=$ $0.19, p=0.72, n=6$ ). No significant correlation was reported between cell death and recovery time.

\section{PET imaging at baseline}

As expected, the regional distribution of radioactivity was in good agreement with that known from in vivo studies in humans for each radiotracer, with the highest uptake in the striatum for both the $\left[{ }^{18} \mathrm{~F}\right] \mathrm{DOPA}$ and $\left[{ }^{11} \mathrm{C}\right]$ raclopride radiotracers (Ito et al., 1999; Nagano et al., 2000), in the raphe and the thalamus for the $\left[{ }^{11} \mathrm{C}\right]$ DASB (Houle et al., 2000; Wilson et al., 2002), and in various components of the limbic system (such as the dorsal ACC, the insula, and the hippocampus) for $\left[{ }^{18} \mathrm{~F}\right] \mathrm{MPPF}$ ligand (Aznavour and Zimmer, 2007; Fig. 2A, Table 2).

\section{Regression analyses}

Interestingly, both $\left[{ }^{11} \mathrm{C}\right]$ raclopride $\mathrm{BP}_{\mathrm{ND}}$ and $\left[{ }^{11} \mathrm{C}\right] \mathrm{DASB} \mathrm{BP}_{\mathrm{ND}}$ collected at baseline were inversely related to the maximal parkinsonian score (corresponding to the full symptomatic motor state) in multiple regions. In particular, negative correlations were reported within both the left GPe and GPi $(r=-0.99, p=$ 0.002 and $r=-0.93, p=0.02$ respectively, Fig. $2 B, n=5$ ) for the $\left[{ }^{11} \mathrm{C}\right]$ raclopride $\mathrm{BP}_{\mathrm{ND}}$ and in the amygdala $(r=-0.88, p=$ $0.049)$, hippocampus $(r=-0.88, p=0.047)$, PCC $(r=-0.98$, 
Table 2. Evolution of $\left[{ }^{18} \mathrm{~F}\right] \mathrm{DOPA}$ uptake and $\left[{ }^{11} \mathrm{C}\right]$ Raclopride, $\left[{ }^{11} \mathrm{C}\right] \mathrm{DASB}$, and $\left[{ }^{18} \mathrm{~F}\right]$ MPPF bindings among the different states and the different regions of interest

\begin{tabular}{|c|c|c|c|c|c|c|c|c|c|c|c|c|c|c|c|c|}
\hline \multirow[b]{2}{*}{ Region } & \multirow[b]{2}{*}{ Part } & \multicolumn{4}{|c|}{$\left[{ }^{18} \mathrm{~F}\right]$ Dopa $K_{\mathrm{i}}$ unit $\times 10^{-3} \mathrm{~min}^{-1}$} & \multicolumn{4}{|c|}{$\left[{ }^{11} \mathrm{C}\right]$ Raclopride $\mathrm{BP}_{\mathrm{ND}}$} & \multicolumn{3}{|c|}{$\left[{ }^{11} \mathrm{C}\right] \mathrm{DASB} B P_{\mathrm{ND}}$} & \multicolumn{4}{|c|}{$\left[{ }^{18} \mathrm{~F}\right] M P P F P_{N D}$} \\
\hline & & $\begin{array}{l}\text { Baseline } \\
(n=7)\end{array}$ & $\begin{array}{l}\text { Early } \\
(n=4)\end{array}$ & $\begin{array}{l}\text { Symptomatic } \\
(n=7)\end{array}$ & $\begin{array}{l}\text { Recovered } \\
(n=7)\end{array}$ & $\begin{array}{l}\text { Baseline } \\
(n=5)\end{array}$ & $\begin{array}{l}\text { Early } \\
(n=4)\end{array}$ & $\begin{array}{l}\text { Symptomatic } \\
(n=6)\end{array}$ & $\begin{array}{l}\text { Recovered } \\
(n=7)\end{array}$ & $\begin{array}{l}\text { Baseline } \\
(n=5)\end{array}$ & $\begin{array}{l}\text { Symptomatic } \\
(n=5)\end{array}$ & $\begin{array}{l}\text { Recovered } \\
(n=4)\end{array}$ & $\begin{array}{l}\text { Baseline } \\
(n=7)\end{array}$ & $\begin{array}{l}\text { Early } \\
(n=4)\end{array}$ & $\begin{array}{l}\text { Symptomatic } \\
(n=7)\end{array}$ & $\begin{array}{l}\text { Recovered } \\
(n=7)\end{array}$ \\
\hline \multirow[t]{2}{*}{ Putamen } & Anterior & $5 \pm 2.2$ & $5.3 \pm 2.2$ & $2.2 \pm 2^{\dagger}$ & $2 \pm 0.8^{\ddagger}$ & $3.7 \pm 0.8$ & $3.8 \pm 0.4$ & $4.2 \pm 0.6$ & $3.3 \pm 0.7^{\ddagger \ddagger}$ & $1.17 \pm 0.2$ & $1.3 \pm 0.3$ & $1.19 \pm 0.2$ & $0.74 \pm 0.2$ & $0.89 \pm 0.2$ & $0.84 \pm 0.2$ & $0.79 \pm 0.1$ \\
\hline & Posterior & $5.2 \pm 2.3$ & $6.2 \pm 3.6$ & $1.9 \pm 2.3^{t / t_{t}}$ & $1.3 \pm 0.7^{\ddagger / * \neq}$ & $4 \pm 0.3$ & $4.6 \pm 0.2$ & $4.9 \pm 0.4$ & $4.1 \pm 0.8$ & $1.09 \pm 0.2$ & $1.24 \pm 0.2^{\dagger}$ & $1.13 \pm 0.2^{\dagger \neq} 0.058$ & $0.62 \pm 0.2$ & $0.72 \pm 0.2$ & $0.7 \pm 0.1$ & $0.65 \pm 0.2$ \\
\hline \multirow[t]{2}{*}{ Caudate } & Anterior & $4.3 \pm 2.3$ & $3.8 \pm 1.9$ & $1.8 \pm 1.7^{\dagger}$ & $1.9 \pm 0.8^{\ddagger} 0.053$ & $3.6 \pm 0.5$ & $3.7 \pm 0.3$ & $4 \pm 0.5^{\dagger} 0.06$ & $3 \pm 1.1^{\ddagger \ddagger}$ & $0.88 \pm 0.2$ & $1.02 \pm 0.3$ & $0.92 \pm 0.2$ & $0.56 \pm 0.2$ & $0.73 \pm 0.2 * 0.06$ & $0.66 \pm 0.2$ & $0.67 \pm 0.1$ \\
\hline & Posterior & $3.8 \pm 2.2$ & $3.8 \pm 2.8$ & $1 \pm 1.1^{t / * t}$ & $1.1 \pm 0.6^{\ddagger / * \neq}$ & $3.1 \pm 0.2$ & $3.5 \pm 0.5$ & $3.6 \pm 0.7$ & $2.8 \pm 1.1$ & $0.9 \pm 0.2$ & $1.04 \pm 0.3$ & $0.94 \pm 0.2$ & $0.38 \pm 0.1$ & $0.44 \pm 0.1$ & $0.42 \pm 0.1$ & $0.45 \pm 0.2$ \\
\hline \multirow{2}{*}{$\begin{array}{l}\text { Ventral } \\
\text { striatum }\end{array}$} & Anterior & $3.4 \pm 1.6$ & $4.1 \pm 1.4$ & $2.8 \pm 1.5$ & $3.2 \pm 0.7$ & $2 \pm 0.6$ & $2 \pm 0.4$ & $2 \pm 0.4$ & $1.8 \pm 0.3$ & $1.11 \pm 0.3$ & $1.18 \pm 0.5$ & $1.15 \pm 0.3$ & $0.64 \pm 0.2$ & $0.81 \pm 0.3$ & $0.72 \pm 0.2$ & $0.69 \pm 0.2$ \\
\hline & Posterior & $2.2 \pm 1$ & $2.7 \pm 1.8$ & $1.1 \pm 0.9$ & $1.2 \pm 0.5$ & $2 \pm 0.3$ & $2.2 \pm 0.2$ & $2.2 \pm 0.3$ & $2.5 \pm 1.4$ & $1.05 \pm 0.2$ & $1.15 \pm 0.4$ & $1.06 \pm 0.3$ & $0.71 \pm 0.1$ & $0.70 \pm 0.1$ & $0.75 \pm 0.1$ & $0.69 \pm 0.2$ \\
\hline \multirow[t]{2}{*}{ Pallidum } & External & $4.4 \pm 2.7$ & $6 \pm 4.2$ & $2.5 \pm 1.6$ & $2.3 \pm 0.6$ & $2.8 \pm 0.3$ & $3 \pm 0.3$ & $3.1 \pm 0.7$ & $3 \pm 0.8$ & $1.18 \pm 0.2$ & $1.38 \pm 0.3^{\dagger}$ & $1.26 \pm 0.3$ & & & & \\
\hline & Internal & $2.1 \pm 2$ & $3.1 \pm 2.3$ & $1.6 \pm 1.2$ & $2.2 \pm 0.8$ & $1.4 \pm 0.2$ & $1.5 \pm 0.2$ & $1.5 \pm 0.4$ & $1.7 \pm 1$ & $1.16 \pm 0.2$ & $1.37 \pm 0.3^{\dagger}$ & $1.21 \pm 0.3$ & & & & \\
\hline \multirow{3}{*}{$\begin{array}{l}\text { Thalamus } \\
\text { ACC }\end{array}$} & & & & & & & & & & $1.55 \pm 0.2$ & $1.8 \pm 0.4^{\dagger} 0.087$ & $1.67 \pm 0.2$ & & & & \\
\hline & Ventral & & & & & & & & & $0.81 \pm 0.3$ & $0.9 \pm 0.4$ & $0.91 \pm 0.3$ & $1.36 \pm 0.4$ & $1.64 \pm 0.6$ & $1.44 \pm 0.3$ & $1.39 \pm 0.3$ \\
\hline & Dorsal & & & & & & & & & $0.58 \pm 0.2$ & $0.7 \pm 0.2$ & $0.67 \pm 0.1$ & $1.84 \pm 0.5$ & $2.21 \pm 0.6$ & $1.99 \pm 0.4$ & $1.88 \pm 0.3$ \\
\hline \multirow{4}{*}{$\begin{array}{l}\text { Frontal } \\
\text { cortex }\end{array}$} & Dorsolateral & & & & & & & & & $0.38 \pm 0.2$ & $0.44 \pm 0.3$ & $0.41 \pm 0.1$ & $1.23 \pm 0.4$ & $1.49 \pm 0.4$ & $1.37 \pm 0.4$ & $1.21 \pm 0.4$ \\
\hline & Medial & & & & & & & & & $0.41 \pm 0.2$ & $0.49 \pm 0.3$ & $0.45 \pm 0.2$ & $1.51 \pm 0.4$ & $1.78 \pm 0.5$ & $1.63 \pm 0.4$ & $1.50 \pm 0.5$ \\
\hline & Orbital & & & & & & & & & $0.51 \pm 0.3$ & $0.62 \pm 0.3$ & $0.54 \pm 0.2$ & $1.13 \pm 0.3$ & $1.34 \pm 0.3^{*} 0.053$ & $1.27 \pm 0.2$ & $1.10 \pm 0.3^{* \neq \neq \neq} 0.066$ \\
\hline & Ventral & & & & & & & & & $0.37 \pm 0.2$ & $0.45 \pm 0.3$ & $0.39 \pm 0.1$ & $1.06 \pm 0.3$ & $1.18 \pm 0.3$ & $1.18 \pm 0.2$ & $1.00 \pm 0.3$ \\
\hline \multirow{3}{*}{$\begin{array}{l}\text { Limbic } \\
\text { structures }\end{array}$} & Amygdala & & & & & & & & & $0.96 \pm 0.3$ & $0.9 \pm 0.3$ & $0.91 \pm 0.3$ & $1.19 \pm 0.2$ & $1.24 \pm 0.2$ & $1.26 \pm 0.1$ & $1.10 \pm 0.2$ \\
\hline & Hippocampus & & & & & & & & & $0.61 \pm 0.2$ & $0.63 \pm 0.2$ & $0.6 \pm 0.2$ & $1.44 \pm 0.3$ & $1.46 \pm 0.2$ & $1.44 \pm 0.3$ & $1.34 \pm 0.3$ \\
\hline & Insula & & & & & & & & & $1.05 \pm 0.2$ & $1.17 \pm 0.3$ & $1.09 \pm 0.2$ & $1.52 \pm 0.4$ & $1.67 \pm 0.4$ & $1.62 \pm 0.3$ & $1.46 \pm 0.3$ \\
\hline Raphe & & & & & & & & & & $1.8 \pm 0.2$ & $2.17 \pm 0.4$ & $2.18 \pm 0.2$ & $0.56 \pm 0.2$ & $0.58 \pm 0.1$ & $0.52 \pm 0.1$ & $0.47 \pm 0.3$ \\
\hline
\end{tabular}

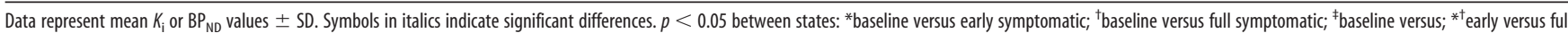
symptomatic; ${ }^{* \neq}$ early symptomatic versus recovered; and ${ }^{\dagger \neq}$ full symptomatic versus recovered.

$p=0.004)$, left insula $(r=-0.90, p=0.037)$, and right dorsal ACC $(r=-0.91, p=0.032)$, as well as the GPe and GPi $(r=$ $-0.92, p=0.025$ and $r=-0.93, p=0.02$, respectively, Fig. $2 B$ ), the posterior striatum $(r=-0.92, p=0.027$ for the caudate, $r=$ $-0.98, p=0.005$ for the putamen), and the posterior ventral striatum $(r=-0.92, p=0.026)$ for the $\left[{ }^{11} \mathrm{C}\right] \mathrm{DASB} \mathrm{BP}_{\mathrm{ND}}(n=$ $5)$ Moreover, we also found a negative correlation between the total time to recovery and the $\left[{ }^{11} \mathrm{C}\right] \mathrm{DASB} \mathrm{BP}_{\mathrm{ND}}$ collected at baseline in the amygdala $(r=-0.94, p=0.017)$, hippocampus $(r=$ $-0.93, p=0.02)$, and the GPe and GPi $(r=-0.94, p=0.019$ and $r=-0.96, p=0.009$, respectively) and the posterior parts of the putamen and the ventral striatum $(r=-0.93, p=0.023$ and $r=$ $-0.97, p=0.005$, respectively, $n=5$ ). Finally, cell death in A9 was negatively correlated with $\left[{ }^{18} \mathrm{~F}\right] \mathrm{DOPA}$ uptake collected at baseline within the GPe and the putamen posterior $(r=-0.90$, $p=0.01$ and $r=-0.85, p=0.03$ respectively, $n=6$ ), whereas cell death in A8 was negatively correlated with $\left[{ }^{11} \mathrm{C}\right]$ raclopride binding collected at baseline within the anterior caudate $(r=-0.92, p=0.025, n=5)$ and the putamen in its anterior $(r=$ $-0.97, p=0.005, n=5)$ and posterior parts $(r=-0.92, p=$ $0.026, n=5$ ). In parallel, there was also a negative relationship between the percentage of cell death in A8 and the level of [11C]DASB binding collected at baseline within the anterior putamen $(r=-0.99, p=0.01, n=4)$. It is worth noting that cell death in A10 was negatively correlated with $11 \mathrm{C}$ ]raclopride binding collected at baseline in both the GPe $(r=-0.96, p=0.008, n=5)$ and the putamen posterior ventral $(r=-0.96, p=0.01, n=5)$, whereas the percentage of total dopaminergic cell death within the SN was inversely related to the level of [11C]DASB binding collected at baseline within the GPi $(r=-0.96, p=0.04, n=4)$.

\section{Changes in the early symptomatic state}

Compared with baseline, ROI-based analyses only revealed a trend for an increase in $\left[{ }^{18} \mathrm{~F}\right] \mathrm{MPPF} \mathrm{BP}_{\mathrm{ND}}$ in the early symptomatic state within the anterior caudate $\left(F_{(1,15)}=8.67, p=0.06\right)$ and the orbitofrontal cortex $\left(F_{(1,15)}=8.52 ; p=0.053\right.$; Table 2$)$. In parallel, SPM analyses revealed a cluster ( $k=563$ voxels $)$ of increased $K_{\mathrm{i}}$ with a peak of activity in the left anterior putamen $(T=$ 7.98; Fig. $3 B$ ); two clusters of increased $\left[{ }^{11} \mathrm{C}\right]$ raclopride $\mathrm{BP}_{\mathrm{ND}}$ in the right and left parts of the posterior putamen $(T=9.11, k=$ 447 voxels and $T=8.42, k=102$ voxels respectively, Fig. $4 B$ ); and three clusters of increased $\left[{ }^{18} \mathrm{~F}\right] \mathrm{MPPF} \mathrm{BP}_{\mathrm{ND}}$ in the right orbitofrontal cortex $(k=139$ voxels, $T=58.28)$, right dorsal ACC $(k=$
660 voxels, $T=55.08)$, and right orbitofrontal cortex extending to the anterior caudate ( $k=119$ voxels, $T=47.8$; Fig. $5 B)$. Finally, regression analysis showed a negative relationship between $\left[{ }^{18} \mathrm{~F}\right]$ DOPA uptake and motor status (both collected in the early symptomatic state) within the right GPe $(r=-0.97, p=0.047$, $n=4$; Fig. $3 D$ ).

\section{Changes in the full symptomatic state}

Compared with baseline, ROI assessment of $\left[{ }^{18} \mathrm{~F}\right] \mathrm{DOPA}$ uptake showed a significant decrease in the putamen (in its anterior $\left(F_{(1,15)}=9.22 ; p=0.049\right)$ and posterior $\left(F_{(1,15)}=12.85 ; p=\right.$ $0.011)$ parts) and the caudate nucleus (in its anterior $\left(F_{(1,15)}=\right.$ $9.35 ; p=0.048)$ and posterior $\left(F_{(1,15)}=16.21 ; p=0.0066\right)$ parts; Fig. $3 A$ ). Interestingly, the $K_{\mathrm{i}}$ values collected during the full symptomatic state were also significantly reduced compared with the early symptomatic state in the posterior striatum $\left(F_{(1,15)}=\right.$ 9.88; $p=0.02$ and $F_{(1,15)}=8.87 ; p=0.037$ for the putamen and the caudate, respectively). The SPM analysis was in good agreement with these latter findings by revealing four clusters of decreased $K_{\mathrm{i}}$ values in the full symptomatic compared with the early symptomatic state within the left and right posterior putamen ( $k=1282, T=6.23$ and $k=527, T=4.96)$, as well as the left and right caudate posterior $(k=490, T=5.42$ and $k=104, T=4.83$, respectively). In the pallidum, the SPM analysis (full symptomatic state vs baseline) revealed a significant decrease of $K_{\mathrm{i}}$ values within the bilateral GPe $(k=547$ voxels and $T=8.63$ for the left side and $k=439$ voxels, $T=6.22$ for the right side, data not shown). In parallel, ROI analysis of $\left[{ }^{11} \mathrm{C}\right]$ raclopride $\mathrm{BP}_{\mathrm{ND}}$ showed a trend for an increase in the anterior caudate nucleus compared with baseline $\left(F_{(1,12)}=8.62 ; p=0.06\right.$; Fig. $4 A$, Table $2)$, whereas the SPM analysis revealed a significant increase of $\left[{ }^{11} \mathrm{C}\right]$ raclopride $\mathrm{BP}_{\mathrm{ND}}$ in the posterior putamen $[T=5.3$ for the cluster $(k=112)$ in the left side and $T=5.12$ for the cluster $(k=$ 98 ) in the right side; Figure $4 C$ ]. Assessment of 5-HT innervation using PET imaging of the SERT with $\left[{ }^{11} \mathrm{C}\right] \mathrm{DASB}$ revealed a significant increase (compared with baseline) in the posterior putamen $\left(F_{(1,7)}=22.34 ; p=0.0064\right)$ and the pallidum in its external $\left(F_{(1,7)}=13.17 ; p=0.025\right)$ and internal $\left(F_{(1,7)}=10.8\right.$; $p=0.04$ ) segments (Fig. $6 A, B$, Table 2 ). At the postsynaptic level, SPM analysis revealed a cluster of increased $\left[{ }^{18} \mathrm{~F}\right] \mathrm{MPPF}$ $\mathrm{BP}_{\mathrm{ND}}$ in the right DLPFC $(k=127$ voxels, $T=6.85$, data not shown). 
A

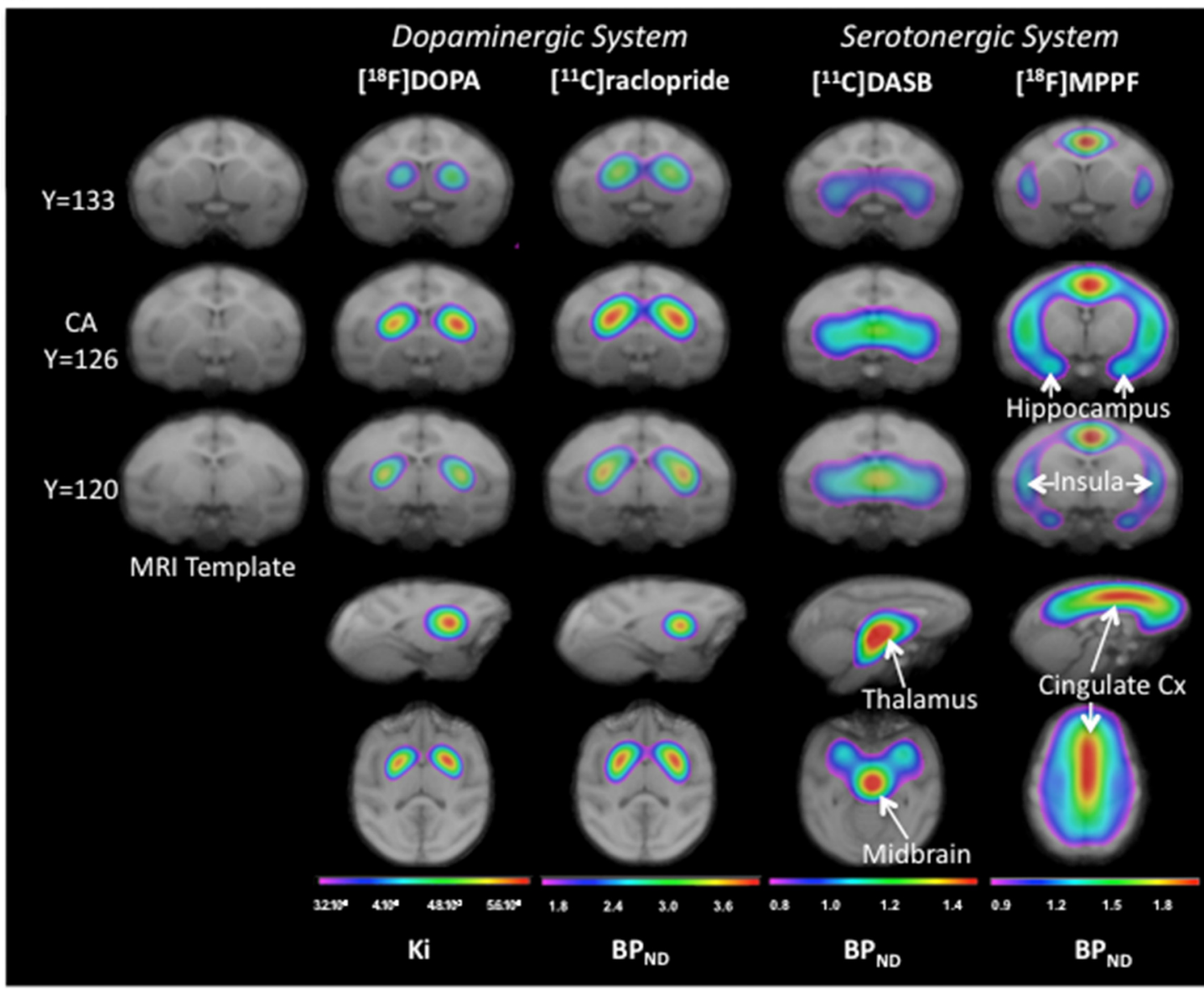

B

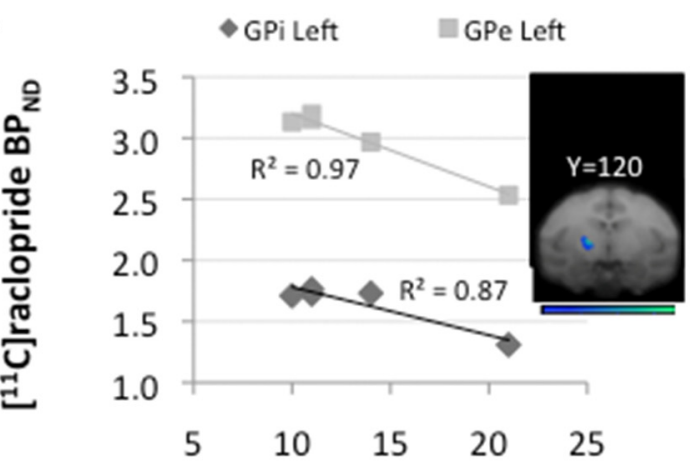

Maximal Parkinsonian Score

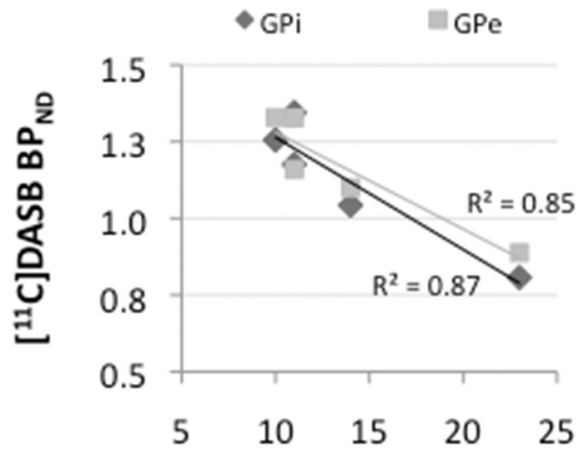

\section{Maximal Parkinsonian Score}

Figure 2. PET imaging at baseline. A, Spatially normalized mean parametric images of each radiotracer collected at baseline superimposed on the brain Macaca fascicularis MRI template (Ballanger et al., 2013). The parametric images are shown in color, whereas the MRIs are shown in grayscale. Colors represent the level of binding expressed as uptake ratio using the cerebellum as a nonspecific reference for each radioligand $\left(K_{\mathrm{i}}\right.$ for $\left[{ }^{18} \mathrm{~F}\right] \mathrm{DOPA}$ and BP${ }_{\mathrm{ND}}$ for $\left[{ }^{11} \mathrm{C}\right]$ raclopride, $\left[{ }^{11} \mathrm{C}\right] \mathrm{DASB}$, and $\left.\left[{ }^{18} \mathrm{~F}\right] \mathrm{MPPF}\right)$. Red represents high $K_{\mathrm{i}}$ or $\mathrm{BP}_{\mathrm{ND}}$, whereas blue denotes low $K_{\mathrm{i}}$ or $\mathrm{BP}_{\mathrm{ND}}$. For each radiotracer, three coronal (first three rows), one sagittal (fourth row), and one transaxial (fifth row) slices are shown. $\boldsymbol{B}$, Negative correlation reported within the pallidum internal (GPi) and external (GPe) parts between both the $\left[{ }^{11} \mathrm{C}\right]$ Raclopride and $\left[{ }^{11} \mathrm{C}\right] \mathrm{DASB} \mathrm{BP}_{\mathrm{ND}}$ collected at baseline and the maximal parkinsonian score obtained in the full symptomatic state $(n=5)$.

Regression analyses showed that $\left[{ }^{18} \mathrm{~F}\right] \mathrm{DOPA}$ uptake collected during the full symptomatic state in the anterior ventral striatum was inversely correlated with the motor status of the monkeys $(r=-0.79, p=0.03, n=7$, data not shown). Negative correlations were also detected between $K_{\mathrm{i}}$ values in the full symptomatic state and recovery time in the anterior ventral striatum and the GPe (respectively $r=-0.91, p=$ 0.005 and $r=-0.83, p=0.022, n=7$; Fig. $3 E$ ). In addition, we found negative relationships between $\left[{ }^{11} \mathrm{C}\right] \mathrm{DASB} \mathrm{BP}_{\mathrm{ND}}$ collected during the symptomatic state in the posterior putamen and the motor score $(r=-0.90, p=0.036, n=5)$ and recovery time $(r=-0.88, p=0.046, n=5)$. There was also a negative correlation between $\left[{ }^{11} \mathrm{C}\right] \mathrm{DASB}$ bindingcollected in the symptomatic state and the recovery time in the GPe $(r=$ $-0.89, p=0.043, n=5$; Fig. $6 C$ ). Finally, there was a positive relationship between the percentage of cell death in $\mathrm{A} 8$ and the amount of $\left[{ }^{11} \mathrm{C}\right]$ raclopride binding in the symptomatic state compared with baseline within the anterior ventral striatum $(r=0.92, p=0.03, n=5)$. The monkeys with greater neuronal loss in the retrorubral area were those with the larger 
A

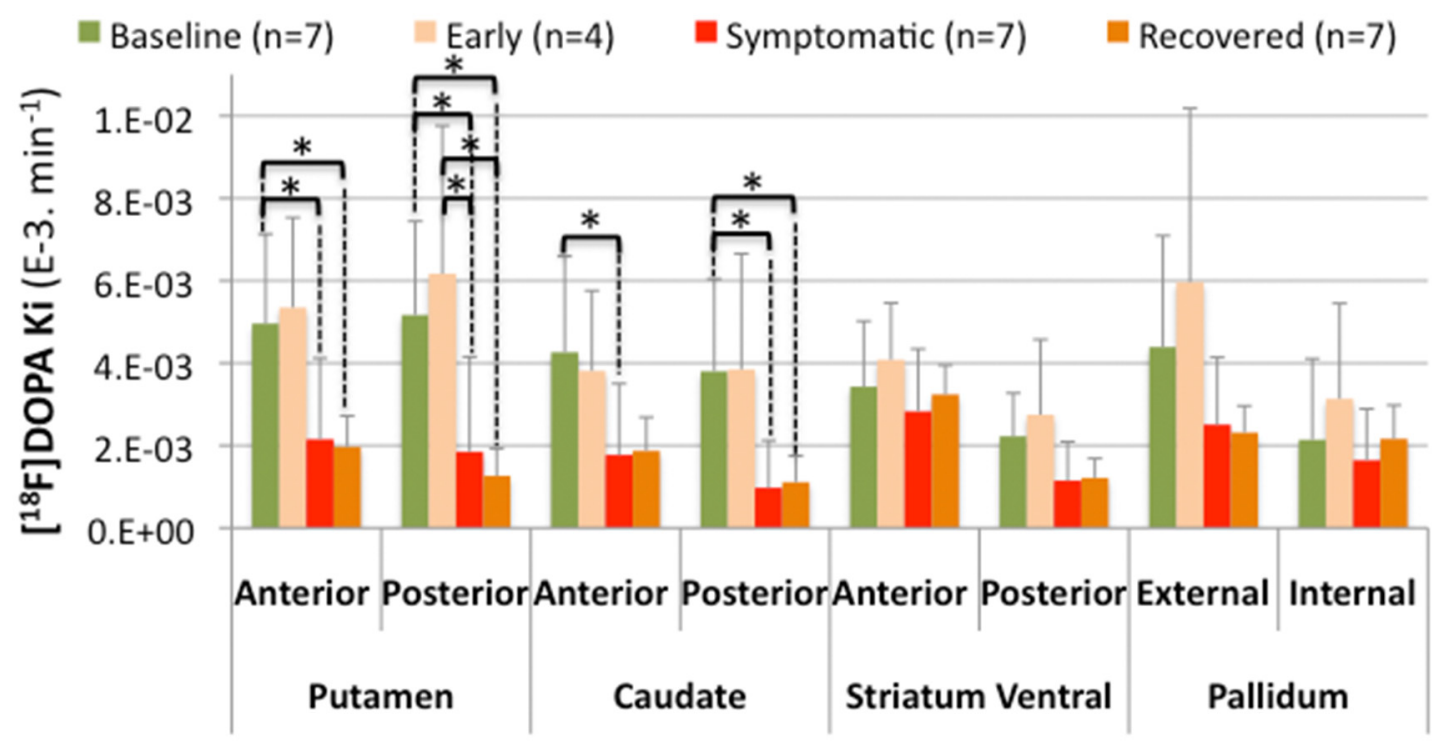

B

C

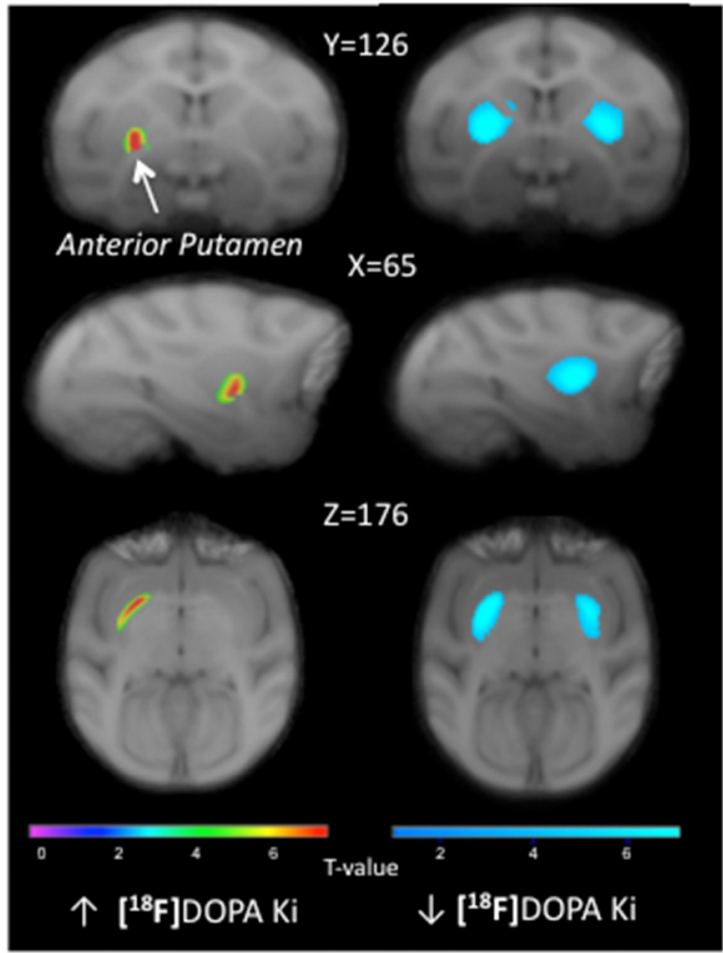

D

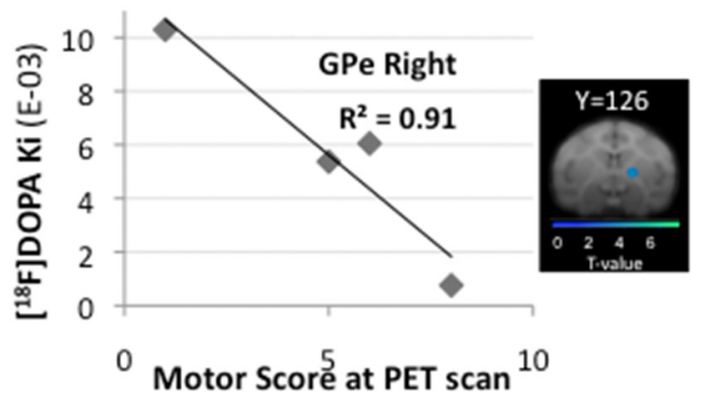

E

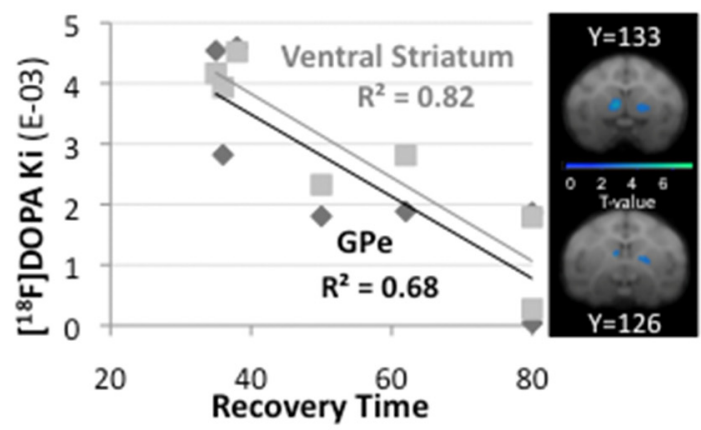

Figure 3. $\left[{ }^{18} \mathrm{~F}\right] \mathrm{DOPA}$ uptake modifications. $A$, ROI assessment of $\left[{ }^{18} \mathrm{~F}\right] \mathrm{DOPA}$ uptake $\left(K_{\mathrm{i}}\right)$ between the different states $(n$ : number of animals in each state). Asterisks indicate significant differences $(p<0.05)$. The bar graphs show the mean \pm SD. B, C, SPM showing changes in $\left[{ }^{18} \mathrm{~F}\right] \mathrm{DOPA}$ uptake $\left(K_{\mathrm{i}}\right)$ rendered over coronal (first row), sagittal (second row), and transaxial (third row) sections of the brain Macaca fascicularis MRI template from Ballanger et al. (2013). The statistical threshold of the voxel-based analyses was set at $p<0.001$ uncorrected. Color bars represent the $t$ value. Specifically, $\boldsymbol{B}$ displays the significant cluster of increase $K_{\mathrm{i}}$ observed within the left anterior putamen in the early symptomatic state compared with baseline and $\boldsymbol{C}$ displays significant clusters (involving the bilateral putamen) of decreased $K_{\mathrm{i}}$ observed in the recovered state compared with baseline. $\boldsymbol{D}, \boldsymbol{E}$, Correlation analyses between $\left[{ }^{18} \mathrm{~F}\right] \mathrm{DOPA}$ uptake $\left(K_{\mathrm{i}}\right)$ and motor score or recovery time during the different states. In particular, motor scores were negatively correlated with $K_{\mathrm{i}}$ values within the external pallidum $(G P e)$ collected in the early symptomatic state $(\boldsymbol{D}, n=4)$ and recovery time was negatively correlated with $K_{\mathrm{i}}$ values within the GPe and the ventral striatum collected during the full symptomatic state $(\boldsymbol{E}, n=7)$. For illustration, results from voxelwise regression with SPM are shown at a more liberal threshold (uncorrected $p<0.05, \boldsymbol{D}$, and $p<0.01, \boldsymbol{E}$ ). Color bars represent the $t$ value.

increase in $\left[{ }^{11} \mathrm{C}\right]$ raclopride binding in the symptomatic state compared with baseline within this specific region. In parallel, we found a negative relationship between the percentage of cell death in A10 and the difference in $\left[{ }^{11} \mathrm{C}\right] \mathrm{DASB}$ binding between the full symptomatic state and baseline in the caudate nucleus in its anterior $(r=-0.97, p=0.03)$ and posterior $(r=$ $-0.99, p=0.006)$ parts $(n=4)$. The monkeys with less neuronal loss in the ventral tegmental region were those with the larger increase in $\left[{ }^{11} \mathrm{C}\right]$ DASB binding in the symptomatic state compared with baseline within this structure. 
A
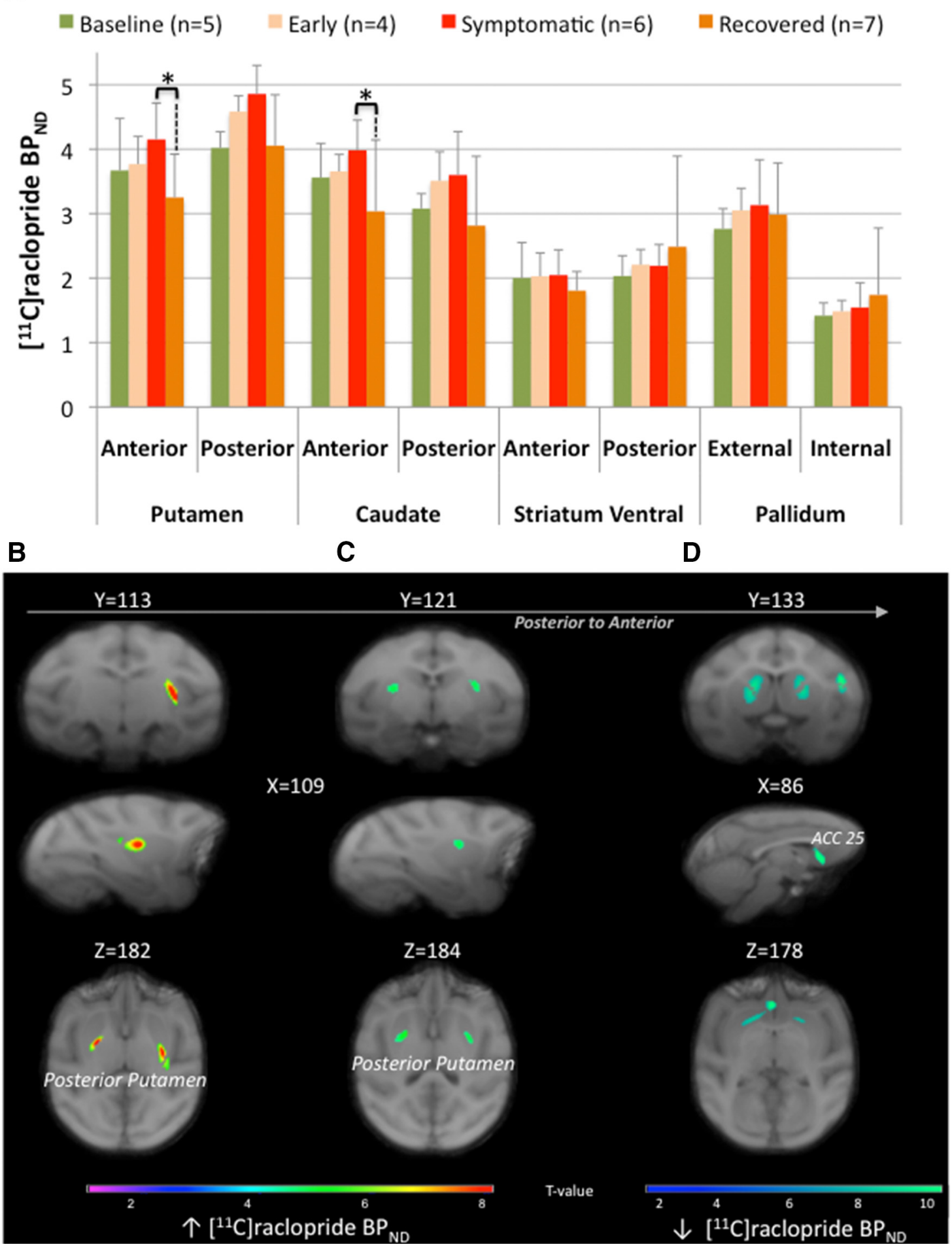

Figure 4. $\quad\left[{ }^{11} \mathrm{C}\right]$ Raclopride binding potential modifications. $A$, ROl assessment of $\left[{ }^{11} \mathrm{C}\right]$ raclopride binding potential $\left(\mathrm{BP}_{\mathrm{ND}}\right)$ between the different states ( $n$ : number of animals in each state). Asterisks indicate significant differences $(p<0.05)$. The bar graphs show the mean \pm SD. B $-\boldsymbol{D}, S P M$ showing changes in $\left[{ }^{11} C\right]$ raclopride binding potential ( $\left(\mathrm{BP}_{\mathrm{ND}}\right)$ rendered over coronal (first row), sagittal (second row), and transaxial (third row) sections of the brain Macaca fascicularis MRI template from Ballanger et al. (2013). The statistical threshold of the voxel-based analyses was set at $p<0.001$ uncorrected. Specifically, $\boldsymbol{B}$ and $\boldsymbol{C}$ display the significant clusters of increase $\mathrm{BP}_{\mathrm{ND}}$ within the bilateral posterior putamen observed in both the early symptomatic $(\boldsymbol{B})$ and full symptomatic (C) states compared with baseline, whereas $D$ displays the significant clusters of decreased $\mathrm{BP}_{\mathrm{ND}}$ within the striatum and the limbic part of the ACC (BA 25) observed in the recovered state compared with the full symptomatic condition. Color bars represent the $t$ value.

Changes in the recovered state

Interestingly, ROI-based analysis showed no statistical difference in $\left[{ }^{18} \mathrm{~F}\right] \mathrm{DOPA}$ uptake between the full symptomatic and recovered states, whereas, compared with the early symptomatic state, $\left[{ }^{18} \mathrm{~F}\right] \mathrm{DOPA}$ uptake was greatly decreased in the posterior striatum $\left(\operatorname{putamen}\left(F_{(1,15)}=13.28 ; p=0.012\right)\right.$ and caudate $\left(F_{(1,15)}=\right.$ $7.82 ; p=0.04)$. Compared with baseline, the loss of $\left[{ }^{18} \mathrm{~F}\right] \mathrm{DOPA}$ uptake was observed in both the putamen in its anterior $\left(F_{(1,15)}=\right.$ 
A

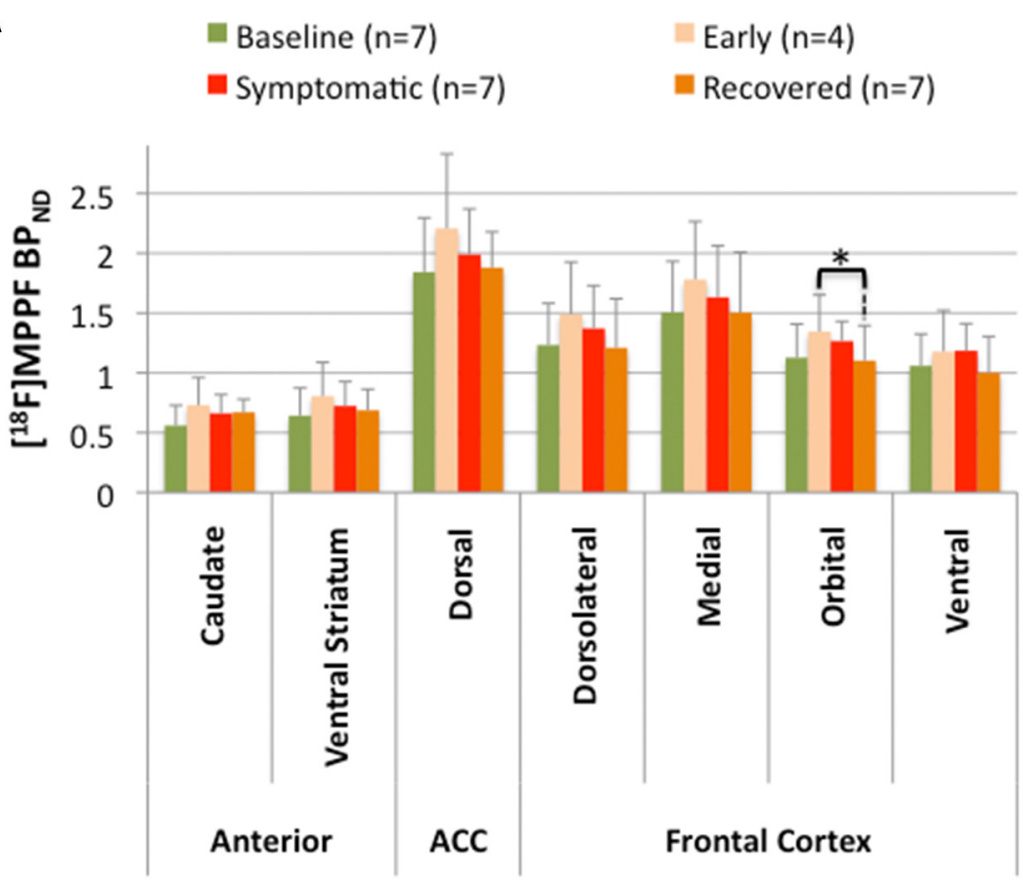

B

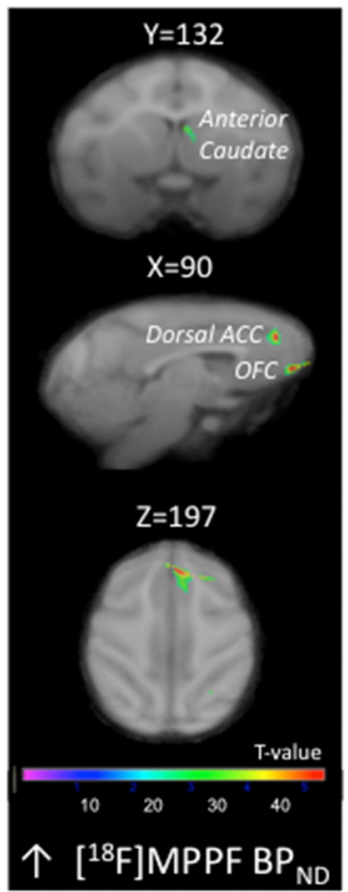

Figure 5. $\quad\left[{ }^{18} \mathrm{~F}\right] \mathrm{MPPF}$ binding potential modifications. $A$, ROl assessment of $\left[{ }^{18} \mathrm{~F}\right] \mathrm{MPPF}$ binding potential ( $\left.\mathrm{BP}_{\mathrm{ND}}\right)$ between the different states ( $n$ : number of animals in each state). The bar graphs show the mean \pm SD. B, SPM showing changes in $\left[{ }^{18} \mathrm{~F}\right] \mathrm{MPPF} B \mathrm{P}_{\mathrm{ND}}$ rendered over coronal (first row), sagittal (second row), and transaxial (third row) sections of the brain Macaca fascicularis MRI template from Ballanger et al. (2013). The statistical threshold of the voxel-based analysis was set at $p<0.001$ uncorrected. Color bars represent the $t$ value. $\boldsymbol{B}$, Significant clusters of increased $\left[{ }^{18} \mathrm{~F}\right] \mathrm{MPPF} \mathrm{BP}_{\mathrm{ND}}$ observed in the early symptomatic state compared with baseline within the anterior caudate and at the cortical level within the orbitofrontal cortex and the dorsal ACC.

$10.48 ; p=0.033)$ and posterior $\left(F_{(1,15)}=17.62 ; p=0.0047\right)$ parts and the posterior caudate nucleus $\left(F_{(1,15)}=14.47 ; p=0.009\right)$, with a trend in the anterior caudate $\left(F_{(1,15)}=8.52 ; p=0.053\right)$. In parallel, ROI analysis of $\left[{ }^{11} \mathrm{C}\right]$ raclopride $\mathrm{BP}_{\mathrm{ND}}$ did not reveal any difference between the recovered state and baseline. However, there was an overall tendency for decreased $\left[{ }^{11} \mathrm{C}\right]$ raclopride $\mathrm{BP} \mathrm{ND}_{\mathrm{N}}$ in the recovered state compared with the symptomatic state. This decrease was significant in the anterior striatum caudate $\left(F_{(1,12)}=14.38 ; p=0.015\right)$ and putamen $\left(F_{(1,12)}=14.20 ; p=\right.$ $0.016)$ (Fig. $4 A$ ). In addition, SPM analysis confirmed the ROI analysis by revealing two clusters within the right anterior putamen $(k=249, T=9.22)$ and the right anterior caudate $(k=80$, $T=8.59)$, as well as a significant cluster of decreased $\left[{ }^{11} \mathrm{C}\right]$ raclopride $\mathrm{BP}_{\mathrm{ND}}$ within the limbic ACC $(k=877, T=14.09$; Fig. $4 D)$. Finally, assessment of the 5-HT system revealed a significant decrease of $\left[{ }^{18} \mathrm{~F}\right] \mathrm{MPPF} \mathrm{BP}_{\mathrm{ND}}$ in the orbitofrontal cortex (compared with the early symptomatic state; $F_{(1,15)}=10.62 ; p=0.03$ ) and a trend for decreased $\left[{ }^{18} \mathrm{~F}\right] \mathrm{MPPF} \mathrm{BP}_{\mathrm{ND}}$ in the orbitofrontal cortex and decreased $\left[{ }^{11} \mathrm{C}\right] \mathrm{DASB} \mathrm{BP}_{\mathrm{ND}}$ in the posterior putamen (compared with the full symptomatic state; $F_{(1,15)}=7.30 ; p=0.066$ and $F_{(1,7)}=7.51 ; p=0.058$, respectively).

Regression analyses showed that recovery time was inversely related to the $\left[{ }^{18} \mathrm{~F}\right] \mathrm{DOPA}$ uptake collected in the recovered state in the anterior ventral striatum $(r=-0.8 ; p=0.034, n=7$, data not shown), as well as to the $\left[{ }^{18} \mathrm{~F}\right] \mathrm{MPPF}$ binding collected in the hippocampus during the recovered state $(r=-0.76, p=0.047$, $n=7$, data not shown) and the $\left[{ }^{11} \mathrm{C}\right] \mathrm{DASB}$ binding $(n=5)$ in multiple regions: the hippocampus $(r=-0.99, p=0.004)$, the amygdala $(r=-0.98, p=0.02)$, the GPe $(r=-0.99, p=0.007)$, the GPi $(r=-0.99, p=0.001)$, the posterior parts of the putamen and ventral striatum $(r=-0.99, p=0.009$ and $r=-0.96$, $p=0.036$, respectively), and the anterior caudate $(r=-0.96, p=$ 0.043 ). In parallel, a positive significant relationship between re- covery time and $\left[{ }^{11} \mathrm{C}\right]$ raclopride binding in the posterior putamen collected in the recovered state was found $(r=0.82, p=$ $0.048, n=7$, data not shown). Finally, cell death in A9 was positively correlated with the delta of $\left[{ }^{18} \mathrm{~F}\right] \mathrm{DOPA}$ uptake between baseline and recovered state within the GPe and the putamen posterior, as well as the putamen posterior ventral $(r=0.83, p=$ $0.04, r=0.81, p=0.049$, and $r=0.84, p=0.04$ respectively, $n=$ $6)$. The monkeys with greater neuronal loss in the SNc were those with a larger decrease in $\left[{ }^{18} \mathrm{~F}\right] \mathrm{DOPA}$ uptake in the recovered state compared with baseline within these three regions.

\section{Discussion}

To our knowledge, this is the first multitracer PET imaging study in nonhuman primates investigating dopaminergic and serotonergic changes both presynaptically and postsynaptically in four different motor states. Two main results emerged. First, different compensatory mechanisms were highlighted, depending on the level of dopaminergic depletion. In particular, our findings supported the importance of dopaminergic neurotransmission in extrastriatal structures (GPe and ACC) for compensation with an early presynaptic regulation followed by more prominent changes in the expression of $\mathrm{D}_{2} / \mathrm{D}_{3}$ dopaminergic receptors during recovery. Second, we identified early changes in the expression of $5-\mathrm{HT}_{1 \mathrm{~A}}$ receptors and presynaptic serotonergic modifications strongly related to the recovery time.

\section{Different DA compensatory mechanisms depending on the parkinsonian state}

During the early symptomatic state, we found an increase in $\left[{ }^{18} \mathrm{~F}\right] \mathrm{DOPA}$ uptake (thought to reflect increased AAAD activity) in the anterior putamen, consistent with the classic hypothesis of dopaminergic striatal compensation in the surviving fibers (Lee et al., 2000; Pifl and Hornykiewicz, 2006). This was associated 
A

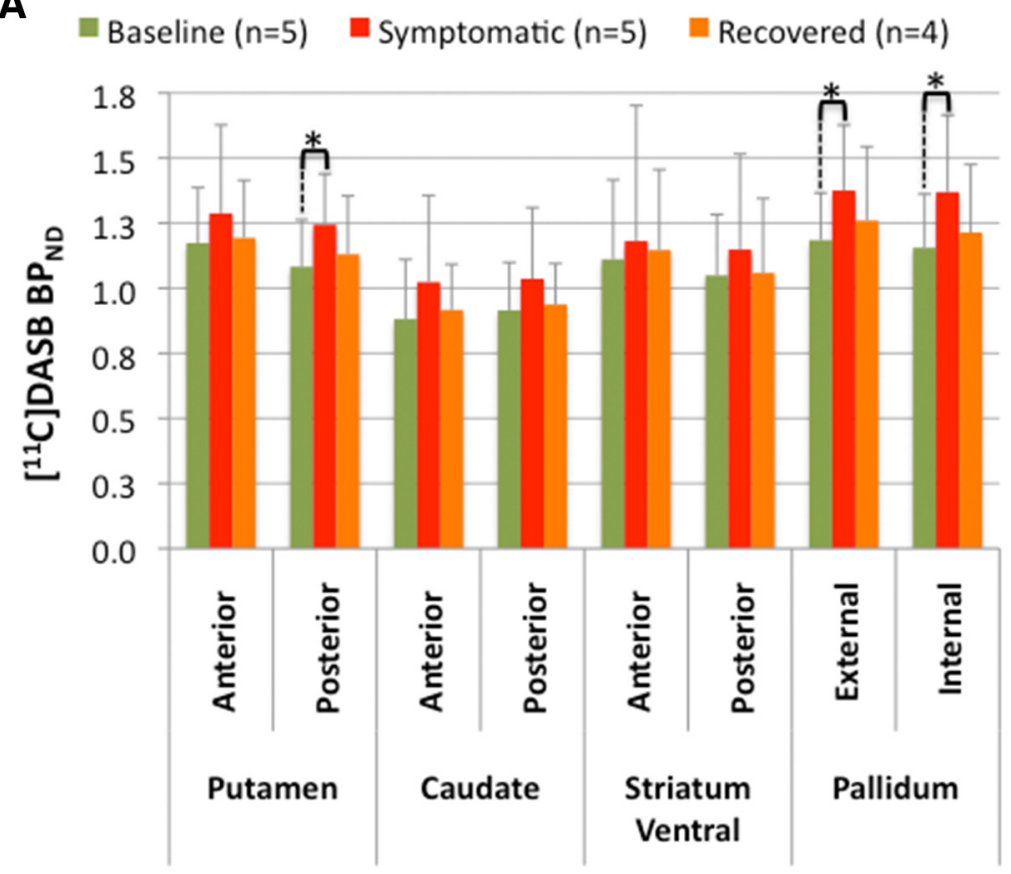

B

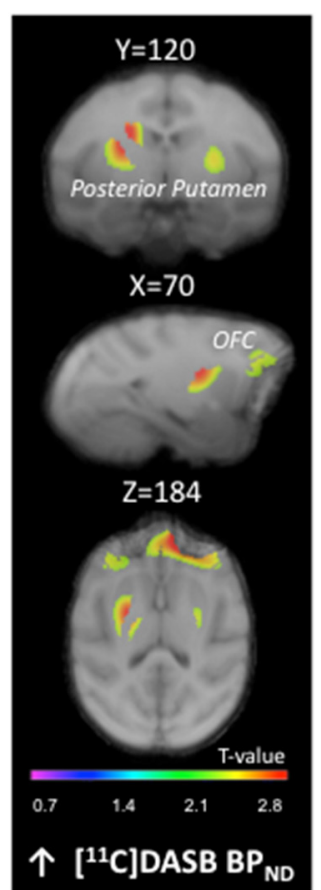

C

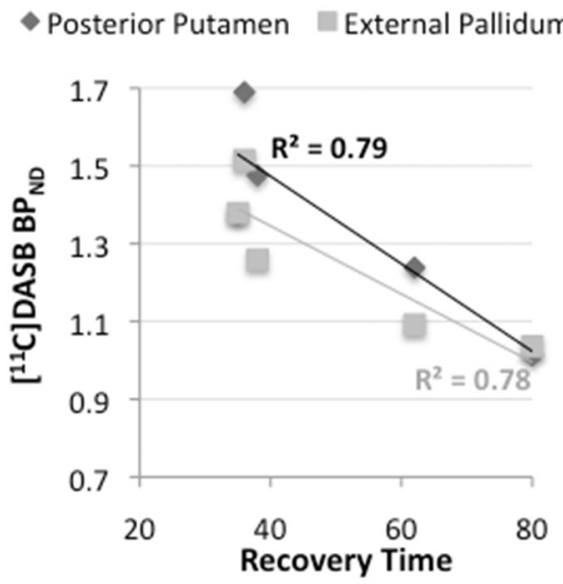

D

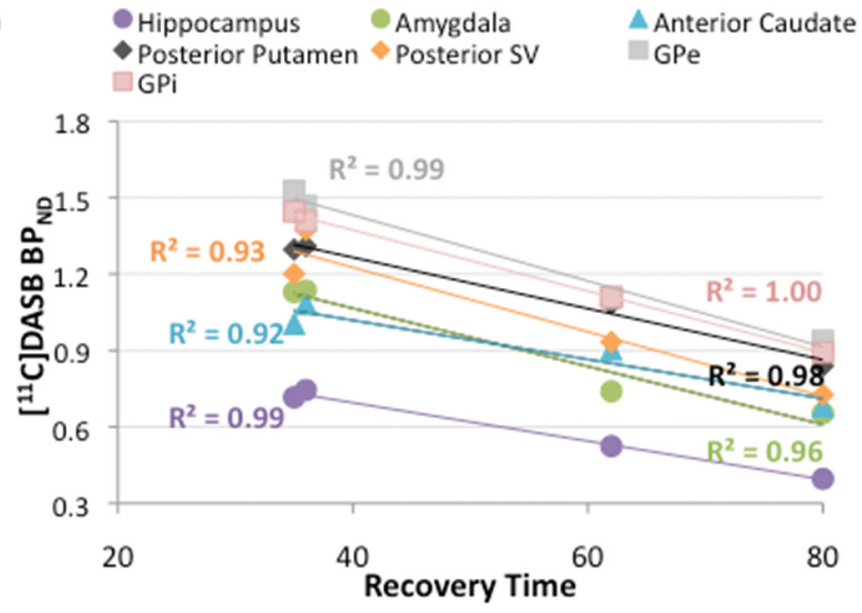

Figure 6. $\quad\left[{ }^{11} \mathrm{C}\right] \mathrm{DASB}$ binding potential modifications. $A$, ROl assessment within the basal ganglia (BG) of $\left[{ }^{11} \mathrm{C}\right] \mathrm{DASB}$ binding potential ( $\mathrm{BP}$ ) between the different states $(n$ : number of animals in each state). Asterisks indicate significant differences $(p<0.05)$. The bar graphs show the mean \pm SD. B, SPM showing changes in $\left[{ }^{11} C\right] D A S B$ BP ${ }_{N D}$ rendered over coronal (first row), sagittal (second row), and transaxial (third row) sections of the brain Macaca fascicularis MRI template from Ballanger et al. (2013). The statistical threshold of the voxel-based analysis was set at $p<0.001$ uncorrected. Color bars represent the $t$ value. Specifically, the figure illustrates the increase of $\left[{ }^{11} C\right] D A S B B_{N D}$ observed in the full symptomatic state compared with baseline within the bilateral posterior putamen. $\boldsymbol{C}, \boldsymbol{D}$, Correlation analyses between $\left[{ }^{11} \mathrm{C}\right] \mathrm{DASB} B \mathrm{P}_{\mathrm{ND}}$ and recovery time during the full symptomatic and recovered states. Overall recovery time was negatively correlated with $\left[{ }^{11} C\right] D A S B B P_{N D}$ within the posterior putamen and the external pallidum during the full symptomatic state $(C, n=5)$ and within the pallidum, the posterior putamen and ventral striatum, the anterior caudate, and the hippocampus and amygdala during the recovered state $(\boldsymbol{D}, n=4)$.

with an increase in $\left[{ }^{11} \mathrm{C}\right]$ raclopride binding (thought to reflect an increased number of dopaminergic $D_{2} / D_{3}$ receptors) specifically in the posterior striatum, similar to PD patients (Nandhagopal et al., 2011). Because parkinsonian motor features mainly depend on the degree of DA depletion in the sensorimotor striatum (Kaasinen et al., 2000; Nandhagopal et al., 2009), it is not surprising that the few remaining fibers in this territory are also involved in the early compensatory phenomenon. A strength of our progressive protocol was the possibility of collecting behavioral and histological markers, which allowed us to perform correlation analyses with the PET data to gain additional information. Such analyses revealed the importance of the relationship between do- paminergic level in the GPe and the appearance and severity of the motor symptoms. In particular, the more the monkeys presented parkinsonian symptoms during the early symptomatic state, the less $\left[{ }^{18} \mathrm{~F}\right] \mathrm{DOPA}$ uptake was observed in the GPe, suggesting its implication in early compensatory mechanisms, probably by maintaining the minimum DA concentration required for normal motor functioning. Interestingly, in de novo parkinsonian patients, an increase of $\left[{ }^{18} \mathrm{~F}\right] \mathrm{DOPA}$ uptake has been reported in the GPi (Whone et al., 2003; Pavese et al., 2012). It is notable that $\left[{ }^{18} \mathrm{~F}\right] \mathrm{DOPA}$ uptake has been shown to reflect the activity of overall brain monoaminergic population. Accordingly, we cannot exclude the possibility that an increase in 
$\left[{ }^{18} \mathrm{~F}\right]$ DOPA uptake might also reflect the AAAD activity of serotonergic terminals (Pavese et al., 2012). This issue needs further study.

The recovered state is particularly interesting because this probably represents the lesional situation closest to PD patients around the time of diagnosis. Indeed, we showed an $\mathrm{SNc}$ cell loss of $\sim 74 \%$, a reduction of $\left[{ }^{18} \mathrm{~F}\right] \mathrm{DOPA}$ uptake by $\sim 63 \%$ in the striatum of recovered monkeys that was higher in the posterior putamen (72\%), and a relative sparing of AAAD activity in the anterior ventral striatum throughout the different states (Doudet et al., 2006; Blesa et al., 2012). These findings are consistent with the extensive loss of dopaminergic neurons that has already taken place when patients are diagnosed with PD (Hornykiewicz and Kish, 1987; Morrish et al., 1998); the characteristic caudorostral gradient of DA degeneration and greater vulnerability of the dopaminergic projection onto the posterior putamen region, as reported in PD patients (Snow et al., 2000; De La Fuente-Fernández et al., 2003); and the partial preservation of the mesolimbic DA innervation also observed in PD patients (Farley et al., 1977; Brooks and Piccini, 2006). Also of interest were the relationships reported between dopaminergic activity within the posterior putamen (as revealed by PET), cell loss in the SNc, the maximal motor impairment, and the recovery time. Indeed, recovered monkeys with higher $\mathrm{SNc}$ cell loss were those with greater parkinsonian impairment and higher reduction of $\left[{ }^{18} \mathrm{~F}\right] \mathrm{DOPA}$ uptake in the posterior putamen compared with baseline. Moreover, the monkeys with longer recovery were those with higher $\left[{ }^{11} \mathrm{C}\right]$ raclopride binding, suggesting greater DA depletion in this structure. Moreover, we provided further evidence that dopaminergic fibers remaining inside the associative limbic territory of the striatum could also be involved in the recovery process (Mounayar et al., 2007; Boulet et al., 2008). This was reflected within the anterior ventral striatum with the negative correlation between recovery time and $\left[{ }^{18} \mathrm{~F}\right] \mathrm{DOPA}$ uptake collected in both the symptomatic and recovered states. The monkeys with high AAAD activity in the anterior ventral striatum had faster recovery. Finally, in both the symptomatic and recovered states, striatal AAAD activity was very low compared with baseline with no significant difference between them, as observed previously (Boulet et al., 2008; Blesa et al., 2012). This lack of difference between these opposite motor states strongly suggests the existence of extrastriatal mechanisms during recovery. Indeed, we demonstrated a significant decrease in the limbic ACC during this period. Moreover, we found that monkeys with a higher level of $\left[{ }^{18} \mathrm{~F}\right] \mathrm{DOPA}$ uptake in the GPe presented faster recovery, confirming the contribution of pallidal dopaminergic neurotransmission also in the recovery mechanisms (Mounayar et al., 2007; Neumane et al., 2012).

\section{Serotonin modifications: implications for compensation or indirect markers of competition with the DA system}

Previously, we suggested a role for serotonergic neurotransmission in motor recovery by showing an increase of striatal serotonergic fibers in recovered monkeys (Mounayar et al., 2007). Here, we report an increase in $\left[{ }^{11} \mathrm{C}\right] \mathrm{DASB}$ binding within the BG during the symptomatic state, confirming and extending previous results obtained with immunohistological (Mounayar et al., 2007) and biochemical (Boulet et al., 2008) techniques. Specifically, the changes mainly involved the posterior putamen and the $\mathrm{GPe}$, in which negative correlations were reported between $\left[{ }^{11} \mathrm{C}\right]$ DASB binding and recovery time. These results strongly suggested a positive involvement of serotonergic innervation in compensation within these structures, at least for functional mo- tor recovery. However, we cannot exclude that this SERT upregulation is not directly responsible for the recovery phenomenon, but rather is an artifact related to the competition between the 5-HT and DA systems. A decrease in DA fibers may allow the sprouting process of serotonergic fibers to take place, leading to an increase in density of serotonergic terminals, as observed in the present study with the $\left[{ }^{11} \mathrm{C}\right]$ DASB radiotracer. Nevertheless, if the 5-HT system is not involved in the recovery process, how can we explain the strong correlations observed in the recovery state between $\left[{ }^{11} \mathrm{C}\right] \mathrm{DASB}$ binding and recovery time in many brain structures (including the BG, hippocampus, and amygdala)? Consistent with this idea, we recently showed that administration of 3,4-methylenedioxy- $N$-methamphetamine to induce a 5-HT lesion in MPTP-recovered monkeys led to the reappearance of the rigidity only, showing the importance of 5-HT transmission in the posterior putamen and the GPi for this particular symptom (Beaudoin-Gobert et al., 2015).

At the postsynaptic level, the present study revealed early changes in the expression of $5-\mathrm{HT}_{1 \mathrm{~A}}$ receptors in subcortical and cortical structures that were less affected by the MPTP-induced dopaminergic degeneration, such as the anterior caudate, the ACC, and the OFC. Although this does not provide direct evidence for the involvement of 5- $\mathrm{HT}_{1 \mathrm{~A}}$ receptors in early compensatory mechanisms, it might be interesting to investigate in humans whether $\left[{ }^{18} \mathrm{~F}\right] \mathrm{MPPF}$ could be a promising biomarker of early degenerative changes in PD. This should be explored further, because postmortem studies have found an increase in $5-\mathrm{HT}_{1 \mathrm{~A}}$ receptor levels in both the orbitofrontal and temporal cortex of parkinsonian patients (Chen et al., 1998; Huot et al., 2012).

Finally, the inverse relationship observed in multiple regions between the $\left[{ }^{11} \mathrm{C}\right] \mathrm{DASB}$ binding collected at baseline and the maximal motor impairment obtained in the full symptomatic stage (or the total time for recovery) raises the question of whether baseline density of serotonergic terminals will predict the intensity of motor impairment after MPTP treatment. Indeed, the monkeys with lower levels of $\left[{ }^{11} \mathrm{C}\right]$ DASB binding at baseline had a higher maximal motor score in the parkinsonian condition. Is it possible that the $\left[{ }^{11} \mathrm{C}\right] \mathrm{DASB}$ radiotracer may be a marker of vulnerability to develop symptom expression? In the same vein, it has been suggested that alterations in availability of serotonergic terminals may be an important factor in the development of anxiety (Reimold et al., 2008; Oler et al., 2009). Accordingly, is there a relationship between the level of anxiety and the vulnerability of some animals to express parkinsonian symptoms and their ability to recover from the parkinsonian state? Further investigations should be performed to elucidate these issues.

In conclusion, the present work highlights the role of pallidal dopaminergic neurotransmission in both the early compensatory mechanisms and the functional recovery mechanisms, with reduced AAAD activity closely related to the appearance or perseveration of motor symptoms. This finding expands possibilities for new treatments (such as cell-based therapies) that could artificially promote dopaminergic levels within the GPe to delay disease expression. In parallel, this study provides preliminary evidence of the role of the serotonergic system in compensatory mechanisms. Nonetheless, future studies are needed to determine whether there are changes in SERT availability in the early symptomatic state and if $\left[{ }^{18} \mathrm{~F}\right] \mathrm{MPPF}$ PET imaging might be a promising biomarker of early degenerative changes in PD. 


\section{References}

Agid Y, Javoy F, Glowinski J (1973) Hyperactivity of remaining dopaminergic neurones after partial destruction of the nigro-striatal dopaminergic system in the rat. Nat New Biol 245:150-151. Medline

Altar CA, Marien MR, Marshall JF (1987) Time course of adaptations in dopamine biosynthesis, metabolism, and release following nigrostriatal lesions: implications for behavioral recovery from brain injury. J Neurochem 48:390-399. CrossRef Medline

Aznavour N, Zimmer L (2007) [18F]MPPF as a tool for the in vivo imaging of 5-HT1A receptors in animal and human brain. Neuropharmacology 52:695-707. CrossRef Medline

Ballanger B, Klinger H, Eche J, Lerond J, Vallet AE, Le Bars D, Tremblay L, Sgambato-Faure V, Broussolle E, Thobois S (2012) Role of serotonergic 1 A receptor dysfunction in depression associated with Parkinson's disease. Mov Disord 27:84-89. CrossRef Medline

Ballanger B, Tremblay L, Sgambato-Faure V, Beaudoin-Gobert M, Lavenne F, Le Bars D, Costes N (2013) A multi-atlas based method for automated anatomical Macaca fascicularis brain MRI segmentation and PET kinetic extraction. Neuroimage 77:26-43. CrossRef Medline

Beaudoin-Gobert M, Epinat J, Météreau E, Duperrier S, Neumane S, Ballanger B, Lavenne F, Liger F, Tourvielle C, Bonnefoi F, Costes N, Bars DL, Broussolle E, Thobois S, Tremblay L, Sgambato-Faure V (2015) Behavioural impact of a double dopaminergic and serotonergic lesion in the non-human primate. Brain 138:2632-2647. CrossRef Medline

Bernheimer H, Birkmayer W, Hornykiewicz O, Jellinger K, Seitelberger F (1973) Brain dopamine and the syndromes of Parkinson and Huntington: clinical, morphological and neurochemical correlations. J Neurol Sci 20:415-455. CrossRef Medline

Bezard E, Gross CE (1998) Compensatory mechanisms in experimental and human parkinsonism: towards a dynamic approach. Prog Neurobiol 55: 93-116. CrossRef Medline

Bezard E, Bioulac B, Gross CE (1998) Glutamatergic compensatory mechanisms in experimental parkinsonism. Prog Neuropsychopharmacol Biol Psychiatry 22:609-623. CrossRef Medline

Blesa J, Pifl C, Sánchez-González MA, Juri C, García-Cabezas MA, Adánez R, Iglesias E, Collantes M, Peñuelas I, Sánchez-Hernández JJ, RodríguezOroz MC, Avendaño C, Hornykiewicz O, Cavada C, Obeso JA (2012) The nigrostriatal system in the presymptomatic and symptomatic stages in the MPTP monkey model: a PET, histological and biochemical study. Neurobiol Dis 48:79-91. CrossRef Medline

Boulet S, Mounayar S, Poupard A, Bertrand A, Jan C, Pessiglione M, Hirsch EC, Feuerstein C, François C, Féger J, Savasta M, Tremblay L (2008) Behavioral recovery in MPTP-treated monkeys: neurochemical mechanisms studied by intrastriatal microdialysis. J Neurosci 28:9575-9584. CrossRef Medline

Brix G, Zaers J, Adam LE, Bellemann ME, Ostertag H, Trojan H, Haberkorn U, Doll J, Oberdorfer F, Lorenz WJ (1997) Performance evaluation of a whole-body PET scanner using the NEMA protocol. National Electrical Manufacturers Association. J Nucl Med 38:1614-1623. Medline

Brooks DJ, Pavese N (2011) Imaging biomarkers in Parkinson's disease. Prog Neurobiol 95:614-628. CrossRef Medline

Brooks DJ, Piccini P (2006) Imaging in Parkinson's disease: the role of monoamines in behavior. Biol Psychiatry 59:908-918. Medline

Chen CP, Alder JT, Bray L, Kingsbury AE, Francis PT, Foster OJ (1998) Post-synaptic 5-HT1A and 5-HT2A receptors are increased in Parkinson's disease neocortex. Ann N Y Acad Sci 861:288-289. CrossRef Medline

De La Fuente-Fernández R, Lim AS, Sossi V, Adam MJ, Ruth TJ, Calne DB, Stoessl AJ, Lee CS (2003) Age and severity of nigrostriatal damage at onset of Parkinson's disease. Synapse 47:152-158. CrossRef Medline

Doudet DJ, Rosa-Neto P, Munk OL, Ruth TJ, Jivan S, Cumming P (2006) Effect of age on markers for monoaminergic neurons of normal and MPTP-lesioned rhesus monkeys: a multi-tracer PET study. Neuroimage 30:26-35. CrossRef Medline

Elfving B, Bjørnholm B, Knudsen GM (2003) Interference of anaesthetics with radioligand binding in neuroreceptor studies. Eur J Nucl Med Mol Imaging 30:912-915. CrossRef Medline

Farley IJ, Price KS, Hornykiewicz O (1977) Dopamine in thelimbic regions of the human brain: normal and abnormal. Adv Biochem Psychopharmacol 16:57-64. Medline

Gaspar P, Febvret A, Colombo J (1993) Serotonergic sprouting in primate
MTP-induced hemiparkinsonism. Exp Brain Res 96:100-106. CrossRef Medline

Gunn RN, Lammertsma AA, Hume SP, Cunningham VJ (1997) Parametric imaging of ligand-receptor binding in PET using a simplified reference region model. Neuroimage 6:279-287. CrossRef Medline

Hornykiewicz O, Kish SJ (1987) Biochemical pathophysiology of Parkinson's disease. Adv Neurol 45:19-34. Medline

Houle S, Ginovart N, Hussey D, Meyer JH, Wilson AA (2000) Imaging the serotonin transporter with positron emission tomography: initial human studies with [11C]DAPP and [11C]DASB. Eur J Nucl Med 27:1719-1722. CrossRef Medline

Huot P, Johnston TH, Visanji NP, Darr T, Pires D, Hazrati LN, Brotchie JM, Fox SH (2012) Increased levels of 5-HT1A receptor binding in ventral visual pathways in Parkinson's disease. Mov Disord 27:735-742. CrossRef Medline

Ito H, Okubo Y, Halldin C, Farde L (1999) Mapping of central D2 dopamine receptors in man using [11C] raclopride: PET with anatomic standardization technique. Neuroimage 9:235-242. CrossRef Medline

Jan C, François C, Tandé D, Yelnik J, Tremblay L, Agid Y, Hirsch E (2000) Dopaminergic innervation of the pallidum in the normal state, in MPTPtreated monkeys and in parkinsonian patients. Eur J Neurosci 12:45254535. Medline

Kaasinen V, Ruottinen HM, Någren K, Lehikoinen P, Oikonen V, Rinne JO (2000) Upregulation of putaminal dopamine D2 receptors in early Parkinson's disease: a comparative PET study with [11C] raclopride and [11C]N-methylspiperone. J Nucl Med 41:65-70. Medline

Lee CS, Samii A, Sossi V, Ruth TJ, Schulzer M, Holden JE, Wudel J, Pal PK, de la Fuente-Fernandez R, Calne DB, Stoessl AJ (2000) In vivo positron emission tomographic evidence for compensatory changes in presynaptic dopaminergic nerve terminals in Parkinson's disease. Ann Neurol 47: 493-503. Medline

Morrish PK, Rakshi JS, Bailey DL, Sawle GV, Brooks DJ (1998) Measuring the rate of progression and estimating the preclinical period of Parkinson's disease with [18F]dopa PET. J Neurol Neurosurg Psychiatr 64:314319. CrossRef Medline

Mounayar S, Boulet S, Tandé D, Jan C, Pessiglione M, Hirsch EC, Féger J, Savasta M, François C, Tremblay L (2007) A new model to study compensatory mechanisms in MPTP-treated monkeys exhibiting recovery. Brain 130:2898-2914. CrossRef Medline

Nagano AS, Ito K, Kato T, Arahata Y, Kachi T, Hatano K, Kawasumi Y, Nakamura A, Yamada T, Abe Y, Ishigaki T (2000) Extrastriatal mean regional uptake of fluorine-18-FDOPA in the normal aged brain-an approach using MRI-aided spatial normalization. Neuroimage 11:760-766. CrossRef Medline

Nandhagopal R, Kuramoto L, Schulzer M, Mak E, Cragg J, Lee CS, Mckenzie J, McCormick S, Samii A, Troiano A, Ruth TJ, Sossi V, de la FuenteFernandez R, Calne DB, Stoessl AJ (2009) Longitudinal progression of sporadic Parkinson's disease: a multi-tracer positron emission tomography study. Brain 132:2970-2979. CrossRef Medline

Nandhagopal R, Kuramoto L, Schulzer M, Mak E, Cragg J, McKenzie J, McCormick S, Ruth TJ, Sossi V, de la Fuente-Fernández R, Stoessl AJ (2011) Longitudinal evolution of compensatory changes in striatal dopamine processing in Parkinson's disease. Brain 134:3290-3298. CrossRef Medline

Neumane S, Mounayar S, Jan C, Epinat J, Ballanger B, Costes N, Féger J, Thobois S, François C, Sgambato-Faure V, Tremblay L (2012) Effects of dopamine and serotonin antagonist injections into the striatopallidal complex of asymptomatic MPTP-treated monkeys. Neurobiol Dis 48: 27-39. CrossRef Medline

Oler JA, Fox AS, Shelton SE, Christian BT, Murali D, Oakes TR, Davidson RJ, Kalin NH (2009) Serotonin transporter availability in the amygdala and bed nucleus of the stria terminalis predicts anxious temperament and brain glucose metabolic activity. J Neurosci 29:9961-9966. CrossRef Medline

Pavese N, Simpson BS, Metta V, Ramlackhansingh A, Chaudhuri KR, Brooks DJ (2012) $\left[{ }^{18} \mathrm{~F}\right] \mathrm{FDOPA}$ uptake in the raphe nuclei complex reflects serotonin transporter availability: a combined $\left[{ }^{18} \mathrm{~F}\right] \mathrm{FDOPA}$ and $\left[{ }^{11} \mathrm{C}\right]$ DASB PET study in Parkinson's disease Neuroimage 59: 1080-1084. CrossRef Medline

Pessiglione M, Guehl D, Hirsch EC, Féger J, Tremblay L (2004) Disruption of self-organized actions in monkeys with progressive MPTP-induced 
parkinsonism. I. Effects of task complexity. Eur J Neurosci 19:426-436. CrossRef Medline

Pifl C, Hornykiewicz O (2006) Dopamine turnover is upregulated in the caudate/putamen of asymptomatic MPTP-treated rhesus monkeys. Neurochemistry International 49:519-524. CrossRef Medline

Politis M, Wu K, Loane C, Kiferle L, Molloy S, Brooks DJ, Piccini P (2010a) Staging of serotonergic dysfunction in Parkinson's disease: an in vivo 11C-DASB PET study. Neurobiol Dis 40:216-221. CrossRef Medline

Politis M, Wu K, Loane C, Turkheimer FE, Molloy S, Brooks DJ, Piccini P (2010b) Depressive symptoms in PD correlate with higher 5-HTT binding in raphe and limbic structures. Neurology 75:1920-1927. CrossRef Medline

Rakshi JS, Uema T, Ito K, Bailey DL, Morrish PK, Ashburner J, Dagher A, Jenkins IH, Friston KJ, Brooks DJ (1999) Frontal, midbrain and striatal dopaminergic function in early and advanced Parkinson's disease A 3D [(18)F] dopa-PET study. Brain 122:1637-1650. CrossRef Medline

Reimold M, Batra A, Knobel A, Smolka MN, Zimmer A, Mann K, Solbach C, Reischl G, Schwärzler F, Gründer G, Machulla HJ, Bares R, Heinz A (2008) Anxiety is associated with reduced central serotonin transporter availability in unmedicated patients with unipolar major depression: a [11C]DASB PET study. Mol Psychiatry 13:606-613, 557. CrossRef Medline

Ribeiro MJ, Vidailhet M, Loc'h C, Dupel C, Nguyen JP, Ponchant M, Dollé F, Peschanski M, Hantraye P, Cesaro P, Samson Y, Remy P (2002) Dopaminergic function and dopamine transporter binding assessed with positron emission tomography in Parkinson disease. Arch Neurol 59: 580-586. CrossRef Medline

Schneider JS, Kovelowski CJ (1990) Chronic exposure to low doses of MPTP. I. Cognitive deficits in motor asymptomatic monkeys. Brain Res 519:122-128. CrossRef Medline
Schneider JS, Rothblat DS, DiStefano L (1994) Volume transmission of dopamine over large distances may contribute to recovery from experimental parkinsonism. Brain Res 643:86-91. CrossRef Medline

Schroeder JA, Schneider JS (2002) GABA(A) and mu-opioid receptor binding in the globus pallidus and entopeduncular nucleus of animals symptomatic for and recovered from experimental Parkinsonism. Brain Res 947:284-289. CrossRef Medline

Snow BJ, Vingerhoets FJ, Langston JW, Tetrud JW, Sossi V, Calne DB (2000) Pattern of dopaminergic loss in the striatum of humans with MPTP induced parkinsonism. J Neurol Neurosurg Psychiatr 68:313-316. CrossRef Medline

Snyder GL, Keller RW Jr, Zigmond MJ (1990) Dopamine efflux from striatal slices after intracerebral 6-hydroxydopamine: evidence for compensatory hyperactivity of residual terminals. J Pharmacol Exp Ther 253:867-876. Medline

Whone AL, Moore RY, Piccini PP, Brooks DJ (2003) Plasticity of the nigropallidal pathway in Parkinson's disease. Ann Neurol 53:206-213. CrossRef Medline

Wilson AA, Ginovart N, Hussey D, Meyer J, Houle S (2002) In vitro and in vivo characterisation of [11C]-DASB: a probe for in vivo measurements of the serotonin transporter by positron emission tomography. Nucl Med Biol 29:509-515. CrossRef Medline

Zigmond MJ (1997) Do compensatory processes underlie the preclinical phase of neurodegenerative disease? Insights from an animal model of parkinsonism. Neurobiol Dis 4:247-253. CrossRef Medline

Zigmond MJ, Acheson AL, Stachowiak MK, Stricker EM (1984) Neurochemical compensation after nigrostriatal bundle injury in an animal model of preclinical parkinsonism. Arch Neurol 41:856-861. CrossRef Medline 